\title{
A Review on the Commonly Used Methods for Analysis of Physical Properties of Food Materials
}

\author{
Tanmay Sarkar ${ }^{1, *,+}$ (D), Molla Salauddin ${ }^{2,+}$, Kohima Kirtonia ${ }^{3,+}$, Siddhartha Pati ${ }^{4,5}$, Maksim Rebezov ${ }^{6,7}$ (D), \\ Mars Khayrullin ${ }^{8}$, Svetlana Panasenko ${ }^{9}$, Lyudmila Tretyak ${ }^{10}$, Marina Temerbayeva ${ }^{11}$, Nadezhda Kapustina ${ }^{12}$, \\ Sanavar Azimova ${ }^{13}$, Lyudmila Gruzdeva ${ }^{14}$, Farrukh Makhmudov ${ }^{13}$, Igor Nikitin ${ }^{8} \mathbb{D}^{\text {, Amirzhan Kassenov }}{ }^{15}$, \\ Mohammad Ali Shariati ${ }^{8}$ (D) and Jose M. Lorenzo $16,17, *$ (D)
}

Citation: Sarkar, T.; Salauddin, M.; Kirtonia, K.; Pati, S.; Rebezov, M.; Khayrullin, M.; Panasenko, S.; Tretyak, L.; Temerbayeva, M.; Kapustina, N.; et al. A Review on the Commonly Used Methods for Analysis of Physical Properties of Food Materials. Appl. Sci. 2022, 12, 2004. https://doi.org/10.3390/ app12042004

Academic Editor: Alessandra Durazzo

Received: 16 November 2021

Accepted: 8 February 2022

Published: 15 February 2022

Publisher's Note: MDPI stays neutral with regard to jurisdictional claims in published maps and institutional affiliations.

Copyright: (C) 2022 by the authors. Licensee MDPI, Basel, Switzerland. This article is an open access article distributed under the terms and conditions of the Creative Commons Attribution (CC BY) license (https:// creativecommons.org/licenses/by/ $4.0 /)$.
1 Department of Food Processing Technology, Malda Polytechnic, West Bengal State Council of Technical Education, Government of West Bengal, Malda 732102, India

2 Department of Food Processing Technology, MMM Government Polytechnic, West Bengal State Council of Technical Education, Government of West Bengal, Plassey 741156, India; molla8759@gmail.com

3 Department of Food Processing Technology, Diamond Harbour Government Polytechnic, West Bengal State Council of Technical Education, Government of West Bengal, Diamond Harbour 743331, India; anneesha162@gmail.com

4 SIAN Institute, Association for Biodiversity Conservation and Research (ABC), Balasore 756001, India; patisiddhartha@gmail.com

5 NatNov Bioscience Private Limited, Balasore 756001, India

6 School of Agricultural Sciences, Liaocheng University, 34 Wenhua Road, Liaocheng 252000, China; rebezov@ya.ru

7 V. M. Gorbatov Federal Research Center for Food Systems of Russian Academy of Sciences, 26 Talalikhina St., 109316 Moscow, Russia

8 Research Department, K.G. Razumovsky Moscow State University of Technologies and Management (The First Cossack University), 73 Zemlyanoy Val, 109004 Moscow, Russia; m.hairullin@mgutm.ru (M.K.); nikitinia@mgutm.ru (I.N.); shariatymohammadali@gmail.com (M.A.S.)

9 Basic Department of Trade Policy, Plekhanov Russian University of Economics, 36 Stremyanny per, 117997 Moscow, Russia; s.v.panasenko@yandex.ru

10 Department of Metrology, Standardization and Certification, Orenburg State University, 13 Pobedy Avenue, 460018 Orenburg, Russia; tretyak_ln@mail.ru

11 Faculty of Engineering and Technology, Innovative University of Eurasia, 45 Lomova St., Pavlodar 140000, Kazakhstan; marvik75@yandex.ru

12 Department of Economic Security and Risk Management, Financial University under the Government of the Russian Federation, 49 Leningradsky Prospekt, 125993 Moscow, Russia; n.kapustina@mgutm.ru

13 Department "Food Safety and Quality of Food Products", Almaty Technological University, 100 Tole bi str., Almaty 050009, Kazakhstan; sanaazimova@mail.ru (S.A.); f.makhmudov@autodom-t.kz (F.M.)

14 Department of Informational Technologies in Jurisprudence and Management Documentation, Russian University of Transport (MIIT), 9b9 Obrazcova Ulitsa, 127994 Moscow, Russia; a1c3@rambler.ru

15 Faculty of Engineering and Technology, Shakarim University of Semey, Semey 071412, Kazakhstan; stat.stat2016@yandex.ru

16 Centro Tecnológico de la Carne de Galicia, rúa Galicia n ${ }^{4}$, Parque Tecnológico de Galicia, San Cibrao das Viñas, 32900 Ourense, Spain

17 Área de Tecnología de los Alimentos, Facultad de Ciencias de Ourense, Universidad de Vigo, 32004 Ourense, Spain

* Correspondence: tanmays468@gmail.com (T.S.); jmlorenzo@ceteca.net (J.M.L.)

+ These authors contributed equally to this work.

Abstract: The chemical composition of any food material can be analyzed well by employing various analytical techniques. The physical properties of food are no less important than chemical composition as results obtained from authentic measurement data are able to provide detailed information about the food. Several techniques have been used for years for this purpose but most of them are destructive in nature. The aim of this present study is to identify the emerging techniques that have been used by different researchers for the analysis of the physical characteristics of food. It is highly recommended to practice novel methods as these are non-destructive, extremely sophisticated, and provide results closer to true quantitative values. The physical properties are classified into different groups based on their characteristics. The concise view of conventional techniques mostly used to analyze food material are documented in this work. 
Keywords: food industry; food physics; quality control; physical methods

\section{Introduction}

The physical properties of food materials have defined those properties that can only be measured by physical means rather than chemical means [1,2]. Food materials are basically naturally occurring biological-originated raw materials that have their own exclusive physical identity that makes them unique in nature [3]. Due to the uniqueness of their physical properties, to properly measure the different physical characteristics of any food materials to get control and understand about the changes in their native physical characteristics with the influence of time-temperature-processing-treatment-exposure, proper measurement techniques for various physical properties of food materials are required with numerous desired outputs [4]. Since the inception of mechanization in measurements, various approaches were introduced by various scientists aiming at different desired outputs with different application purposes. In the case of food materials, proper measurements of different physical attributes are very much important for new product design and development, shelf-life enhancing and, most importantly, to maintain food safety and quality parameters [5-7]. Among the different conventional methods, most of the methods are time-consuming, laborious, and destructive, since during measuring operations the food products were either completely destroyed, were wasted, or got contaminated [8]. That means a huge loss results when measuring the physical attributes of a food product and also during processing. The proper measurement of different attributes is not possible, which results in improper measurement with respect to the different processing conditions [9]. Also, conventional measurement techniques are incapable of capturing the real-time changes of the product's physical characteristics with changes in process parameters and also incapable of finding out the complex behavior of the inter-associated and intra-associated critical physical parameters $[10,11]$. Currently, with the help of emerging digital techniques, various novel techniques for measuring different physical properties of different food products are being introduced in the market along with evolutionary sophisticated high-end instruments with state-of-the-art facilities. Currently, these instruments are capable of capturing and estimating the real-time changes in food's physical properties with almost zero product loss $[10,12]$. These new-age measurement approaches also provide reliable data and information concerning the physical properties and functional behavior of food components, which is critical and helps the food processors evaluate the possible substitution of food ingredients in new or existing food products. For the proper design of a new food product, we need a huge set of data under a different set of parameters with different operational conditions and this is only possible with the help of emerging novel digitalized measurements techniques [13]. Therefore, data generation is one of the prime driving factors behind the demand for measurement techniques involving novel methods [14]. There are several books [15-18] and review works [19-21] available about techniques for the analysis of the chemical and physical properties of food materials, but only a limited number of studies on the commonly used analysis techniques, their principles, applications, advantages, and disadvantages. In this review, the contemporary methodologies for estimating the physical properties of food materials are covered, aiming at a complete study of measurements of food materials.

\section{Importance of Physical Analysis Methods in the Food Industry}

Physical testing in the food industry refers to the methods used to evaluate a food product's varied physical qualities. Color, viscosity, weight, thickness, granulation size, and texture are all common food product attributes examined. Physical testing in the food industry is usually employed as a quality indication, but it can also be used to ensure product consistency. Manufacturers can utilise this to evaluate product value, connect a product to consumer perception, and, in some situations, ensure food safety when a 
product must be cooked. Unusual physical outcomes could indicate a problem with the shelf life, production, and supply chain. Physical testing has a distinct advantage for businesses in terms of monitoring their suppliers' items and catching problems before customers complain. Furthermore, when physical qualities are assessed in conjunction with consumer research, the physical test specification ranges can be linked to desirable product information. This can help determine preferences in terms of appearance, such as a certain hue, or texture, such as viscosity, firmness, and consistency. Because a product's physical properties impact customer perspective and acceptability, determining optimal physicochemical characteristics can aid product development teams and retailers with knowledge on the part for drawing conclusions. Technologies that help in the physical analysis of food material is a subject of growing interest because of their non-destructive nature (Figure 1). Since the last half of the 20th century there has been an increase in the search for new physical analysis methods for the food industry. In Scopus and the Web of Science, a moderate number of papers are being published on this topic, and most of the published articles are research articles. The published works available in the field basically describe the working procedures, results, and validation of some particular methods on specific food products. Keyword searching reveals that the techniques to analyze the physical property of food materials are gaining the interest of researchers from academia, as well as from industry (>25 in 2022 to date, $>75$ in 2021 and $>50$ in 2020). Bibliometric analysis has revealed that there are several research papers available on the techniques for analysis of various physical properties of food materials, but there is a need for a concise review of the principles, specific field of applications, merits, and demerits of the techniques to provide an overall view of the rigorously practiced methods.

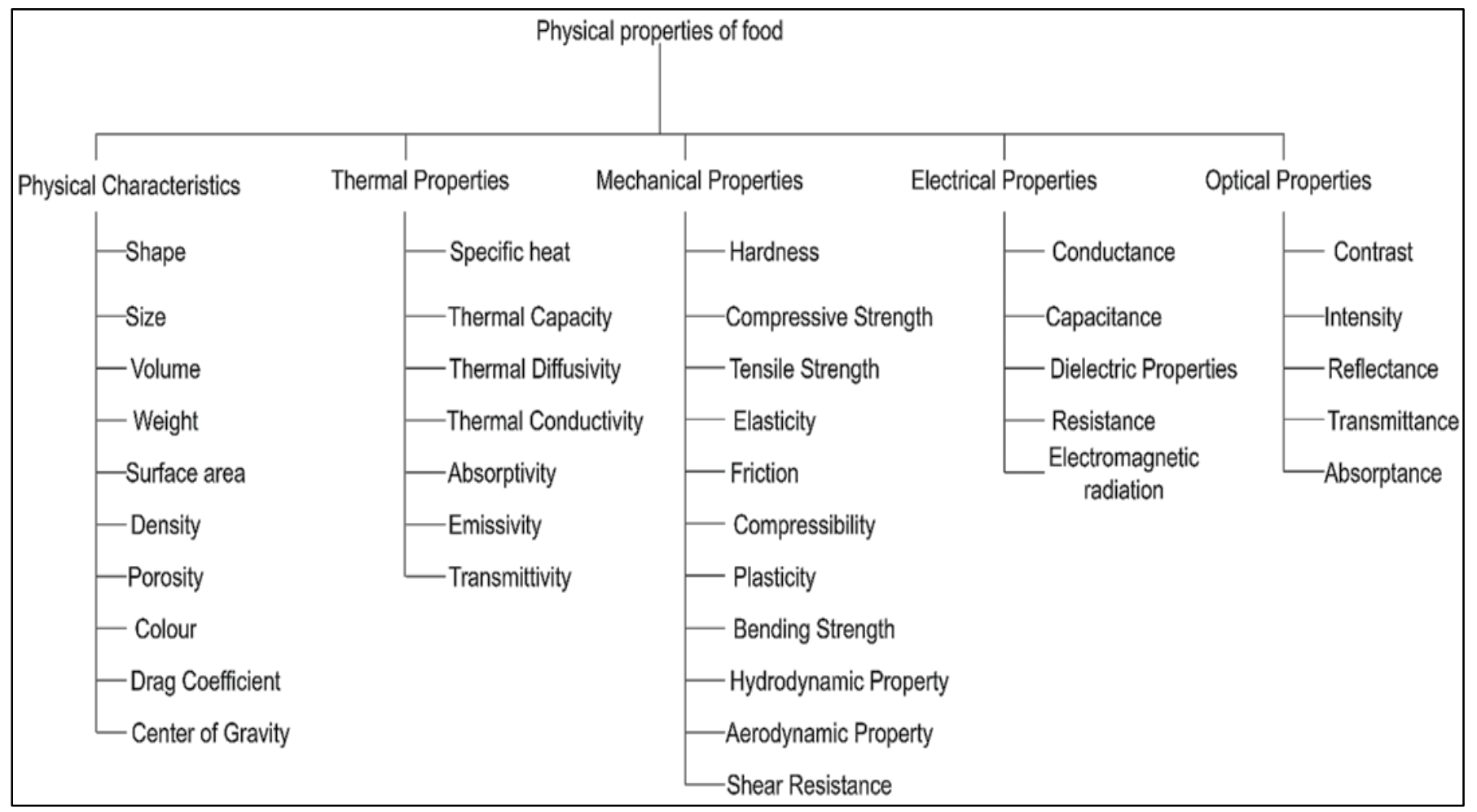

Figure 1. Classification of physical properties of food materials.

\section{Techniques for Non-Destructive Physical Methods}

During recent years, researchers have applied several novel techniques in the field of physical property assessment of different food commodities. Depending on the physical states of the food material, the methods of physical techniques that have been employed are described in Figure 2. 


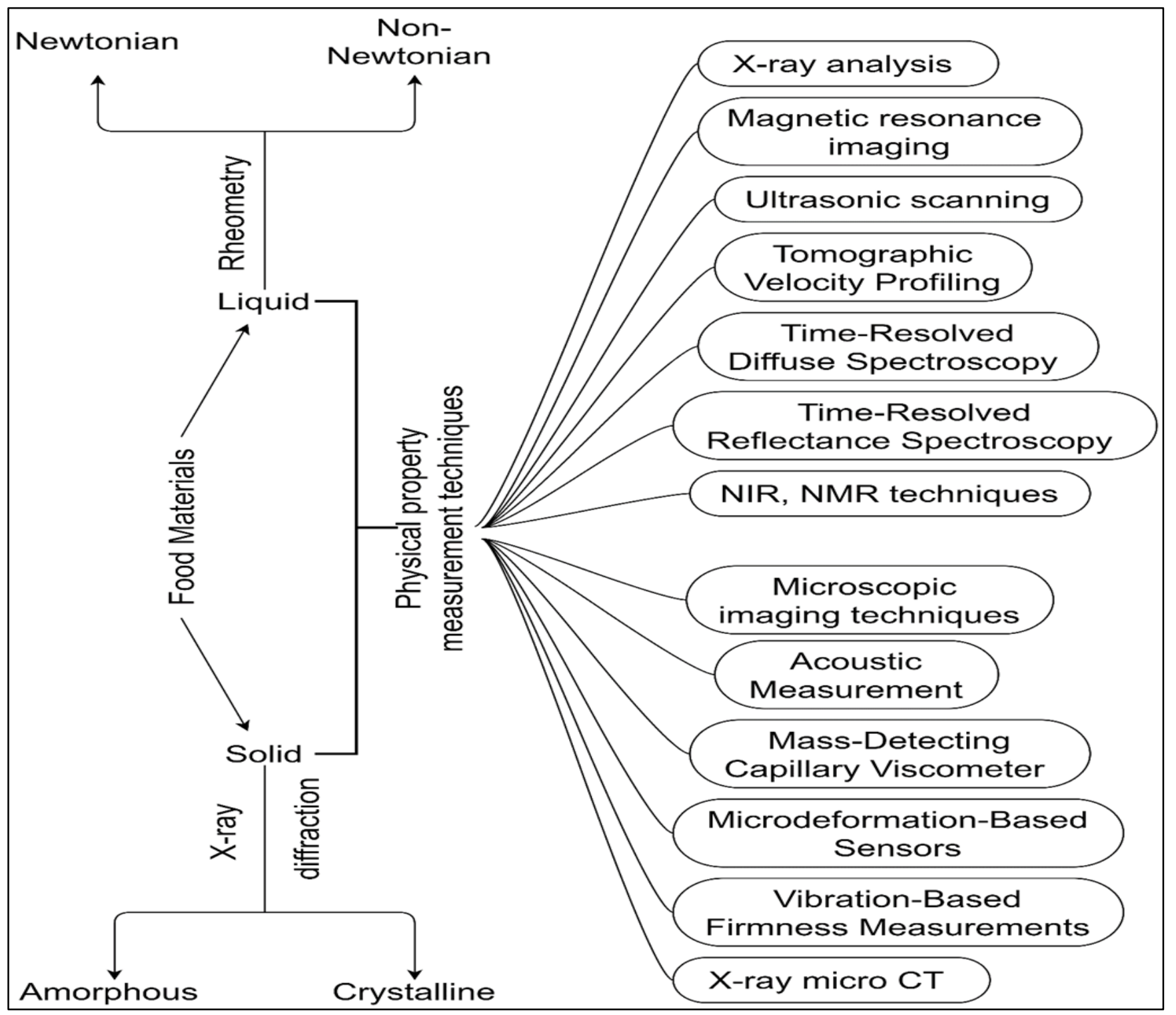

Figure 2. Novel techniques for assessment of physical properties of food materials.

\subsection{Ultrasonic Wave-Based Analysis}

The ultrasonic frequency is beyond audible to human hearing. These acoustical or mechanical waves have a frequency of $\geq 20 \mathrm{kHz}$. An ultrasonic scanning system can be used for food diagnostic purposes (physicochemical properties like flow rate, structure, composition, and physical state), especially for soybean, honey, cereals, meat, and aerated foods (Table 1) [22]. Volume estimation, firmness, maturity of fruits [23-25], rheological properties of cereal products [26], determination of fat percentage in meat [27], and defect detection in cheese [28] have been measured or conducted with ultrasound. Ultrasound velocity, attenuation coefficient, signal and wave amplitude, acoustic impedance, and relative delay are the parameters considered for analysis of food materials [29,30]. The techniques provide the following advantages: portable, simple, low power consumption, lower operational cost, adaptability for both liquid and solid foods, and environmentally friendly [29]. The limitations of the techniques are shock wave generation, followed by degradation of products, and radical formation followed by off-flavor formation in the products subject to analysis. Surface characteristics and homogeneity of products may affect test efficiency and the development of mass transfer resistance [22]. 


\subsection{Young's Modulus and Poisson's Ratio}

The Sitkey technique was applied by researchers to determine the Poisson's ratio as a function of moisture content and Young's modulus as a function of loading rate. A material testing machine was used to perform the test. It found that there is a negative correlation between the Poisson's ratio of the grains and moisture content. On the other hand, the reverse was found for the loading rate. For the grains, Young's modulus is inversely proportional to moisture content and loading rate [31].

\subsection{Compressibility Analysis through High-Pressure Processing (HPP)}

Processing food by applying high pressure is now an impactful technique to preserve different foods. High pressures exhibit bulk compression loading on the food. At high pressure (400-1000 MPa) and adiabatic conditions with a pressure change of $100 \mathrm{MPa}$, there is a change in water temperature of $3{ }^{\circ} \mathrm{C}$. Pressurization of food material leads to changes in rheological properties, thermodynamic properties, and compression heating [32]. It is a non-destructive green technique, but the food composition and solute concentration are the limiting factors for the efficacy of the technique. Moreover, it is not suitable for solid food products [32].

\section{Techniques for Mechanical Impact Assessment}

Non-periodic, non-continuous, and instantaneous load is defined as a mechanical impact. If two convex bodies are in contact and one of the bodies has a high velocity, there may be different effects, such as wave propagation and contact in the impact area [33].

\subsection{Hertz Contact and Impact Measurement Parameters}

Food samples show that there can be three categories of impact measurement parameters. These parameters can be listed as absorbed energy, load velocity, impact energy, and rebound energy. All of them are categorized into three groups: (i) maximum impulse, bruise dimensions, permanent and maximum deformation, and critical deep; (ii) rebound velocity, the slope of the force-time curve $(S)$, maximum impact force $(F)$, and the ratio of F and S; and (iii) impact duration (ID), time of impact (TI), TI-ID, etc. [34,35]. These parameters possess a linear correlation with the ripeness stage of the fruit [35]. The use of this correlation quality and these maturity indexes for fruits can be developed with the help of parameters. Researchers have proven that the elasticity modulus of fruits is correlated to their maturity stages and have classified the fruits based on the ripening stage [36,37]. In this technique, it has been assumed that the contact area is circular and frictionless, and that deformation should be within the limit of deformation. Thus, the technique is suitable only for good quality, sphere-shaped, and smooth-surfaced fruits. But the method is useful for collision mechanic models [35].

\subsection{Vibration Study and Mechanical Impact Based Method}

The study of vibrational characteristics leads to the determination of fruit firmness using an elasticity modulus. From different studies, it can be concluded that waves transmitted through the fruit surface with velocity transmission provide highlights of fruit texture attributes such as firmness, as the ripening condition of fruits is correlated to velocity of wave propagation [38]. An advantageous feature of the technique is that it supports condition monitoring from a distance. For predictive maintenance, well-established signal assessment methods are available, supported by a variety of commercially accessible sensors for diverse operational scenarios. Meanwhile, the demerits are as follows: it is difficult to pinpoint the source of a problem; fracture development is hard to track; and there are a lot of prerequisites for the development of a good system architecture [39].

\section{Techniques for Texture Profile Analysis (TPA)}

To correlate the rheological property of food with the mechanical testing method is a great challenge. Instron universal testing machines (UTM) are successfully employed 
to understand food rheology. TPA is an instrumental method that compresses the testing material for two times the mechanical parameters that are quantified from the force deformation curve (Table 2) [40,41]. Figure 3 represents the physical properties of fruits and vegetables and their techniques for measurement.

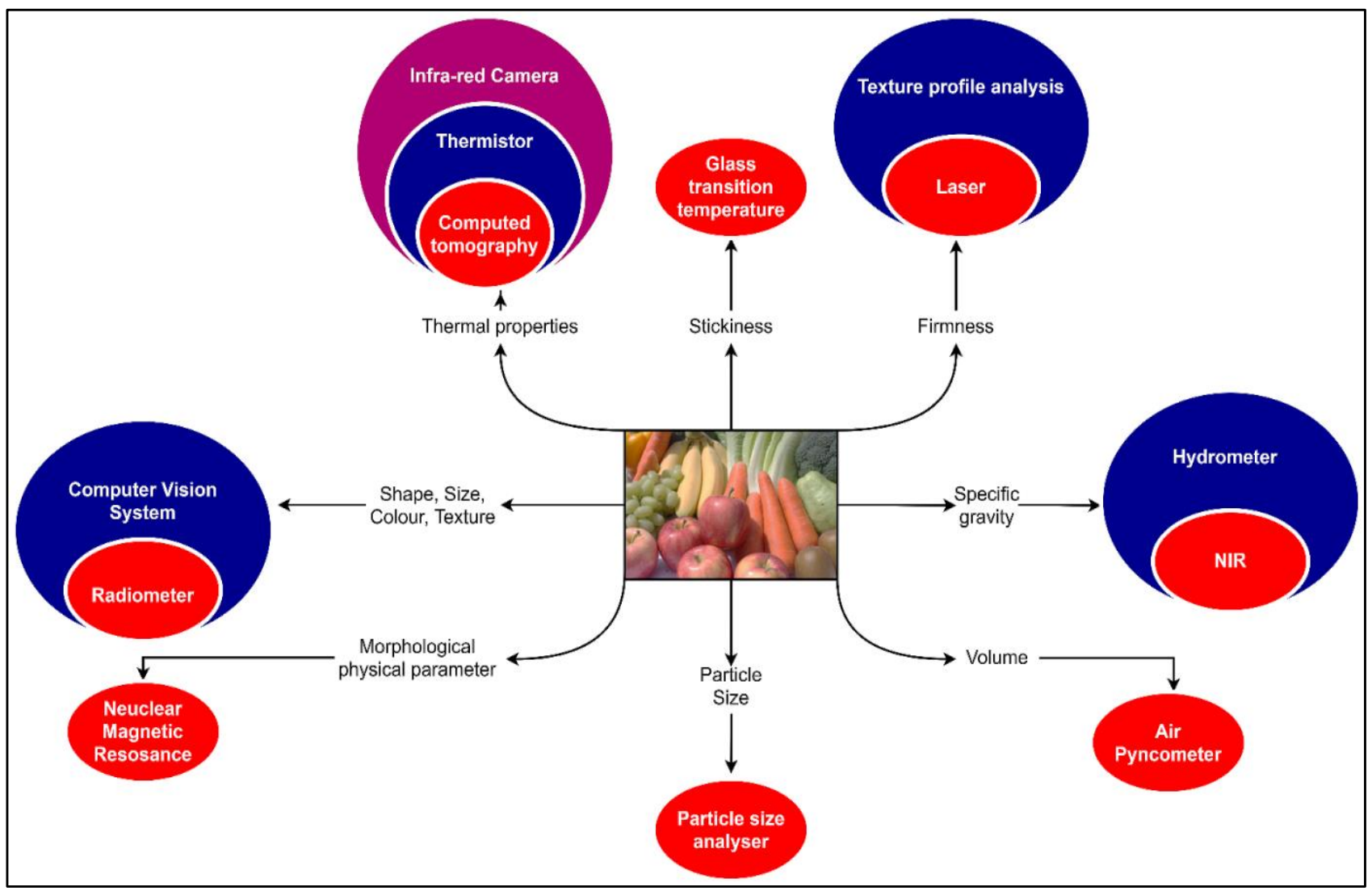

Figure 3. Physical properties of fruits and vegetables and their techniques for measurement.

\section{TPA Performance}

Several studies have proved the need for TPA. The effect of reduction in fat content on cheddar cheese texture has been observed by researchers. It has been found that the rheological properties like hardness, adhesiveness, springiness, and values from the instrumental analysis are extremely correlated with the sensory analysis [42]. Researchers have observed that composition and storage facilities significantly affect the resilience, chewiness, and firmness of sliced cheese [43]. Near-infrared hyperspectral imaging is one of the non-invasive techniques for TPA measurement. Researchers have successfully implemented the technique for salmon fillets [40]. Biospeckle activity is another novel optical technique for firmness analysis that has been implemented to ascertain apple firmness [44]. The TPA performance depends on the sample height, compression speed, diameter ratio of sample and probe, initial height over the sample, and geometry of the probe used [45]. Despite the numerous published publications on the use of instrumental TPA to define solid foods, it cannot be considered a unified method. This is because the instrumental TPA, in all of its forms, has a number of fundamental defects (e.g., calibrationrelated issues, mechanical issues) [46]. The sample height is important in determining the TPA. Similarly, friction between sample and plates, overall dimension of sample and aspect ratio may affect the analysis results. However, it is obvious that bite size is not the determining factor for the texture in real cases [46], although the simplicity of the approach and its cost-intensive nature make it a popular method in food texture analysis. 


\section{Novel Techniques for Viscosity Analysis}

\subsection{Tomographic Velocity Profiling}

Tomographic velocity profiling is one of the emerging technologies. The working principle lie in the measurement of the velocity profile, which is specific to a cross-section of pipe and thereby determines the drop in pressure for a specific length. Unlike regular tube viscometry, whose theory is based on volumetric formulas for measuring viscosity data points, tomographic viscometry involves shear rate data points from the viscosity profile $[47,48]$. The non-invasive and non-destructive manner of operation, as well as the in-line measurement of rheological parameters (e.g., slip velocity, yield stress, and shear viscosity) are the advantageous features of the process. In most liquid food, scattering particles are present that determine the flow characteristics. For food materials where scattering particles are more abundant, a portion of the velocity profile may be recorded instead of profiling the entire velocity [49].

\subsection{Mass-Detecting Capillary Viscometer (MDCV)}

The MDCV has been used to study the rheology of dairy products for a shear rate range measuring the variation of liquid-mass with time. The operation process is simple and easy. A wide range of shear rate $\left(1-10^{3} / \mathrm{s}\right)$ can be measured for non-Newtonian fluids [50]. The $\mathrm{MDCV}$ is capable of measuring the continuous change in viscosity over a range of shear rate through the measurement of alteration in the mass of liquid with respect to time.

\subsection{Ultrasonic Doppler Velocimetry (UDV)}

Viscosity is an important physical parameter of food. UDV can be effectively employed for viscosity determination. In the industrial scale crystallization process, UDV is employed. Flow behavior, complex rheological behavior such as yield stress, and viscoelasticity can also be measured [51]. The non-intrusive design of UDV is advantageous, apart from that it has other merits like ease of installation, lower contamination chance, lower chance of leakage, insensitivity toward density, viscosity, and temperature of fluid, and the potential to work with corrosive liquid. But operating UDV is difficult for fluids with very low velocity. To reflect the ultrasonic signal, the liquid stream must contain any kind of particles and/or bubbles and, therefore, UDV is not suitable for highly clean fluids or water. The particle distribution within the fluid may affect the performance of the UDV [51].

\subsection{Reflectance Sensor}

A reflectance sensor acts on the principle of reflectance at the liquid surface as it does not transmit through the liquid. Evaluation of the viscosity of the food products is done with the help of density and viscosity sensors. This method is gaining increased popularity because of its robustness and also because flow rate and vibrations have no impact on the process [52]. Upon reflection on the surface of the liquid, the shear wave propagates approximately one-half of a wavelength (i.e., $~ 1 \mathrm{~mm}$ ) within the sample, thus near-surface characteristics should be the indicative of the bulk, or otherwise useful information cannot be generated. Frequencies at which commercial shear transducers operate are substantially quicker than most real-world fluid deformations [53].

\subsection{Ultrasonic Wave Propagation-Based Sensors}

Food materials are susceptible to the different processing techniques applied to them. That is why minimal processing with low-density ultrasonics are non-destructive. Textural analysis can be done by measuring velocity and attenuation. If tissue analysis of whole fruit is required, then a single-touch system may be used for whole fruit [30]. Continuous and on-line analysis is possible with this technique. Sensors may malfunction in extreme alterations in temperature and radical convection. The other drawbacks for the technique are inflexibility in the methods of scanning and limitations in testing distances [54]. 


\section{Emerging Techniques of Measurement of Firmness}

The firmness of food products is a reflection of the quality of food. It is one of the attributes upon which consumer acceptance is decided. Available tests are generally destructive tests that are not applicable to firmness-based grading [55].

\subsection{Non-Destructive Impact-Based Measurements}

Fruit impact with sensing elements and dropping the fruit on force transducers are the two methods for impact measurement. Several studies have shown the use of the non-destructive detectors or sensors for impact analysis [56].

\subsection{Non-Destructive Microdeformation-Based Sensors}

Deformations may occur in fruits during compression. To mitigate this issue, nondestructive sensors are used that can measure the extent of deformation during compression. A spherical plunger is used for indenting the fruit surface, taking care of the damage issue $[57,58]$. A piezoelectric sensor or analogue record the non-destructive force-deformation curve that is positioned at the back of the compression plunger [59]. The maximum pressure and slope of the plunger are the limiting factors for this technique [60].

\subsection{Vibration-Based Technique}

This technique involves the fruit being subject to blows from a small hammer. The produced mechanical vibration is estimated with the help of accelerometers or laser vibrometers. The computer system is attached to a measuring instrument to calculate the frequency response spectrum obtained from the time domain signal. The resonance frequencies are directly related to the mechanical properties of the fruit. Hence, fruit firmness can be characterized from these data. The resonance frequency and fruit firmness are directly proportional [61]. The demerit of an accelerometer-aided technique is that in this technique the device needs to be attached to the fruit surface, which may cause surface patches. Apart from this, concentration of excitation energy and un-uniformity are the other drawbacks of this technique, while the laser vibrometer technique can measure the real-time vibrational signal without surface contact with the food $[62,63]$.

\subsection{Image-Analysis-Based Methods}

The first criteria to attract consumers to fruits are probably texture and appearance. A machine vision system may be applied for judging fruit characteristics. Light scattering is a reflection of the structural characteristics of the fruit. Hence, it can be used to judge fruit firmness. The optical system method is successfully employed to determine apple fruit firmness. A $670 \mathrm{~nm}$ laser was used for light scattering. The camera and stereomicroscope were set up for measuring their scattering. The region of interest can be selected according to the studies targeted using hyperspectral imaging $(\mathrm{HI})$ to accommodate the drawbacks of juncture assessment and/or background noise. Both spectral and spatial information can be gathered with this process [64]. Smartphone-based digital image analysis is an emerging section in food quality analysis [65]. The image-analysis-based methods are suitable for non-invasive analysis of meat, fish, and poultry products (Figure 4). The nondestructive and non-invasive characteristics, in-line adaptability, and little or no sample preparations are the features that make the technique popular. However, the complexity, cost involvement, and sensitive detectors are the limitations for HI. While the requirement of a large database, computational complexity, and the requirements for large storage space and fast computers are the limiting factors for digital image analysis. 


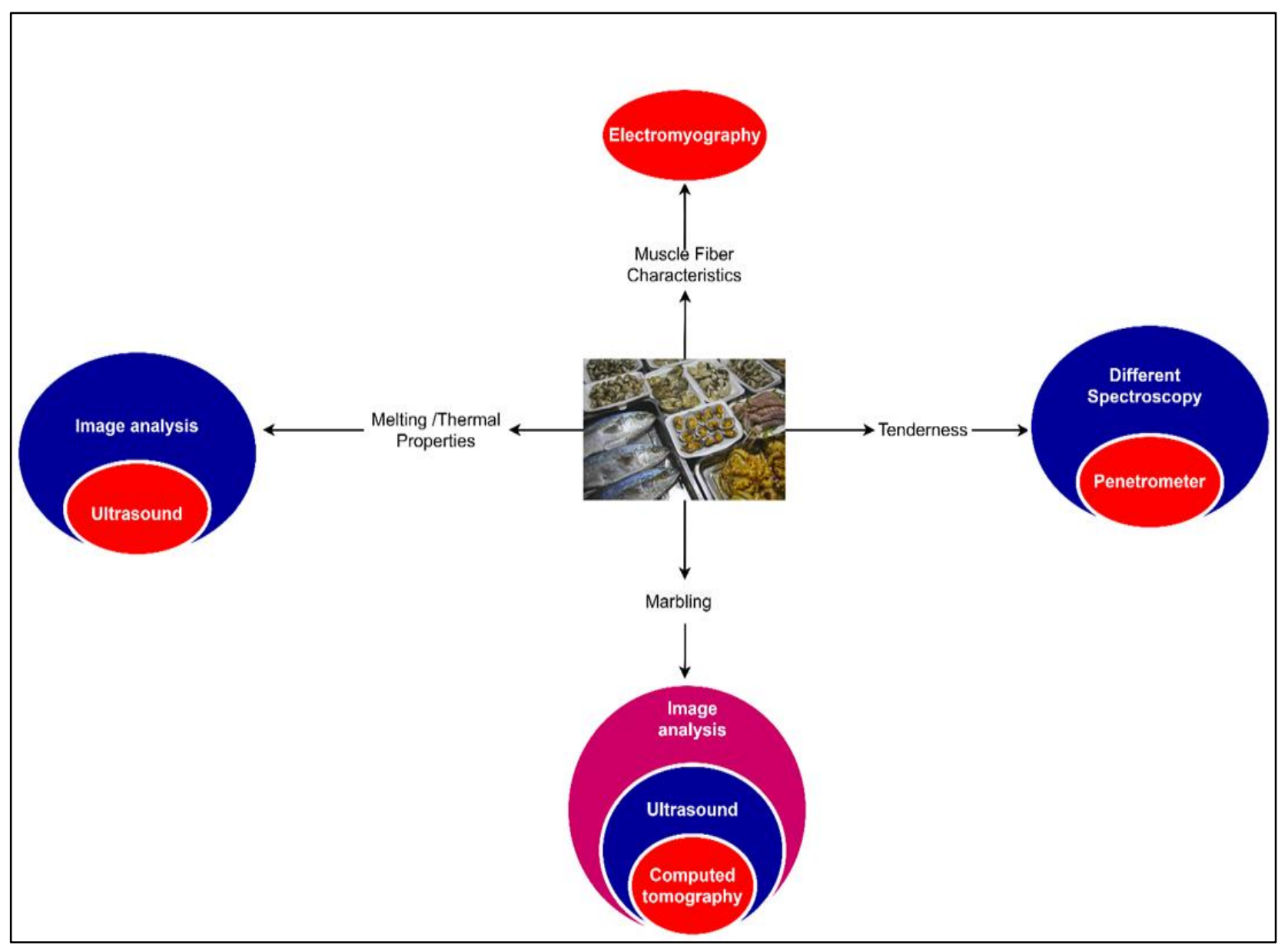

Figure 4. Physical properties of meat, fish, and poultry products and their techniques for measurement.

\subsection{Near-Infrared Spectroscopy (NIR)}

In NIR, the electromagnetic range is set between $780 \mathrm{~nm}$ and $2500 \mathrm{~nm}$. The incident radiation on the food sample is measured with a spectrophotometer. Radiation on the sample may be absorbed, reflected, or transmitted, and therefore each phenomenon reflects food characteristics. From absorption data, the chemical composition of the sample can be measured. Meanwhile, the microstructure of tissue can be related to scattering [66]. It is a non-invasive, rapid method and no or very little sample preparation is required for this technique [67]. Overlapping and the presence of multiple peaks are abundant in NIR spectra. Thus, multivariate analyses coupled with statistical analysis are required to extract the significant information [68].

\subsection{Ultrasonic Wave Propagation Methods}

It is the non-destructive method that assists in the determination of the freshness of food materials. A pair of ultrasonic transducers $(80 \mathrm{kHz})$ is used to determine the mealiness in food. One of the transducers transmits a pulse through food tissue and thereby, based on the internal texture of the food, the tissue absorbs energy. Another transducer gets the transmitted pulse as an emerging signal [30]. Peak frequency, attenuation, and the flight and wave velocity of transmitted signals are analyzed to determine the firmness characteristics, such as elastic modulus and bioyield strength. For peach (0.542), pear (0.730), and apple (0.792) strong correlation coefficients have been observed for the prediction model of bioyield strength [69]. The requirement of a relatively smooth surface and complications for food materials with irregular shapes (e.g., jackfruit) are the limitations of this method. 


\subsection{Time-Resolved Diffuse Spectroscopy (TRS)}

To characterize highly diffusive media, the TRS method can be employed. A laser light pulse is used in TRS, and it is injected into the sample under study. Here, the absorption coefficient is represented by $\mu \mathrm{a}$, and $\mu$ is the transport scattering coefficient. These two can be evaluated from the time distribution curve [70]. High temporal and spectral resolution is obtained in this non-destructive technique. The absorption characteristics are representative of the bulk material and not a characteristic of surface attributes. The absorption coefficients and transport scattering coefficients are under $1 \mathrm{~cm}^{-1}$ and $25 \mathrm{~cm}^{-1}$, respectively, for fruits with thin skin [71]. Thus, it is not suitable for thick-skinned fruits.

\subsection{Nuclear Magnetic Resonance (NMR) Spectroscopy and Magnetic Resonance Imaging (MRI)}

The NMR technique has served as a novel method for food analysis for many years. It can easily detect the presence of sugar, water, and oil in food particles. The sensory quality of potatoes has been studied using NMR imaging [72]. The MRI images can be used for firmness analysis predictions with ANN [73]. Researchers have considered MRI and NMR for orange firmness analysis, and built a robust model with 0.84 and 0.92 Pearson correlation coefficients [74]. It is a non-invasive method and can be used for real-time, inline inspection of food quality. The cost-intensive nature, safety concerns, and requirement for skilled operators restrict the use of these techniques in developing countries [75].

\section{Techniques for Crispness Measurement}

The quality of dry food may be measured by several attributes, one of which is crispness, but defining crispness for all food commodities is difficult as it may differ from one product to another. Crispness of fruits and vegetables may be defined as the cracking sound that evolved from sudden fracture upon the application of force [76-78]. Besides sensory analysis, there are instrumental methods also available for crispness measurement.

\subsection{Mechanical Measurement of Crispness}

Mechanical tests applied to crispness measurement may be categorized as compression, shear, and flexure test. The sensory and Instron tests have been used to measure the crispness level of different foods. To conduct the test, various cutting devices are employed and it has been found that, in cereals, shear force may be the crispness indicator [79-82]. The method is simple and rapid, and the output results are easy to interpret and, moreover, are convenient in an industry environment and economically viable [83]. Because of unusual shapes, sizes, and/or the simultaneous presence of non-crisp portions in food, crispness analysis is found to be difficult with this method. Humidification of crisp products causes negative correlations between force and crispness value [84].

\subsection{Acoustic Measurement of Crispness}

This method is based on the cracking or rupturing sound created during the fracture of the food material [85]. The sound is developed during machine crushing and recorded. Crispness has been measured using sound signal features, and the result was cross-checked by the sensory panelist. An audio recording system is employed with the features: a dynamic microphone, Waver Studio software, and sound card. A neural network technique and principal component regression were used to analyze sound features to predict the crispness [80].

\subsection{Ultrasonic Measurement of Crispness}

The ultrasonic pulse-echo technique has been used to study the crispness of biscuits [86], ciabatta crust [87], chicken nuggets [88], cornflakes [89], and apples [90,91]. It has been found that the velocity of longitudinal sound and sensory crispness has a strong correlation [76]. It is a non-destructive and rapid method. The key challenge for this technique is to standardize the numbers of the acoustic peak, force peak, and sound pressure level, as these parameters may vary for individual products [92]. 


\section{Woolliness and Mealiness Measurement}

Mealiness and wooliness in fruits are such characteristics that are absolutely not acceptable. Mealiness is a state in fruits when sandy texture is observed because of a lack of juiciness [93]. Woolliness is described as a dry, soft texture of fruit with a loss of aroma and flavor. As these attributes of fruits are not easily detectable in the selection chain, nondestructive instruments may be an alternative option. The best possible mechanical test to detect apple mealiness may be the shear stress rupture test. Non-destructive measurement has become more popular these days. These include impact response, ultrasonic wave propagation, NMR spectroscopy, time-resolved reflectance spectroscopy, imaging, and chlorophyll fluorescence.

\subsection{Impact Response-Based Techniques}

To detect mealy fruits based on sensory analysis, healthy or mealy fruits are classified. We observed that mealiness is highly correlated with maximum resistance to impacts. From the results of the impact-response test, it is easy to classify healthy and mealy fruits. In other experiments, signal detection tools are used, specifically receiver operate curves (ROCs), to get the nature of discriminate analysis with varying cut-off points [94]. Researchers have found that peak accelerometer output and firmness possess lower correlation coefficients for apple (0.55), while the same for pear (0.80) and peach (0.92) are relatively better [95]. The impact location and angle greatly influence the impact response, and therefore the characteristics of the fruit surface may affect the final result $[95,96]$.

\subsection{Detection Method Based on Quantity of Free Juice}

Mealiness and woolliness are attributes that are defined by a lack of juiciness. The confined compression test has been done with peach and apple. The texture analyzer inserts the load cylinder until the fruit pulp gets maximum deformation. After compression, the fruit juice is extracted and taken in a drying paper. The juiciness is measured as the area stained by the juice. That will in turn correlate to mealiness and woolliness [97]. The process is simple and easy to implement, but the expert opinion is that dependency is the main challenge for this technique [98].

\subsection{Techniques Based on Imaging}

Images developed from a light microscope may be useful for differentiating between fresh and mealy fruits. Parameters such as area and perimeter (cell parameter), and two roundness parameters are set for evaluation from the images. When the tensile loading test was performed for mealy fruit, fewer broken cells were found in the surface after fracture than for fresh fruit [99]. Multiconstituent information can be accessed with non-destructive techniques, but time- and cost-intensive methods, maintenance of the equipment, and operator skill are other limiting factors [93].

\subsection{Time-Resolved Reflectance Spectroscopy (TRS)}

Mealiness in fruits was evaluated by time-resolved laser spectroscopy [100]. A confined compression test was done to categorize mealy and non-mealy fruits. The coefficients (optical) were set as variables that will produce functions of identification for mealiness. A calibration curve is prepared with 15 TRS variables. This curve will classify the two types of fruits. It is a non-destructive analysis technique, although the dependency on expert opinion is the major disadvantage $[93,101]$. The absorption coefficient varies for different fruits, and therefore it is difficult to standardize the absorption coefficients for each type of fruit and for the physical property intended to be measured and subjected to experimentation [101].

\subsection{The Use of Modeling for Predicting Mealiness}

Fruit mealiness is evaluated with linear regression models [93]. During storage, the level of mealiness was studied by the mechanistic model from the turgor pressure of 
the tissue. The technique is simple and easy to implement, and a high coefficient of correlation (0.96) has been found. The limitations of the technique are the requirement for an independent data set for model validation, non-consideration of the state variables such as pectin and symplastic water content, and no changes in temperature and oxygen concentration have been assumed [102].

\subsection{Methods Based on Chlorophyll Fluorescence}

After absorbance of light or electromagnetic waves by any substance, emission at different wavelengths is called fluorescence. Photosynthesis activity is associated with chlorophyll fluorescence measurement. Loss of chlorophyll implies a decrease in the photosynthesis rate, which ultimately shows the ripening of vegetables. A study showed that in the chlorophyll fluorescence kinetics of fruits, with the decrease in fluorescence value, an increase in the mealiness-level fluorescence values was observed. The destructive method showed $82 \%$ classification efficiency, while the same for chlorophyll fluorescence was $85 \%$ [103]. Based on this result, the mealiness level may be categorized and a more accurate result is obtained than from destructive tests [104]. The method is rapid, noninvasive, and easy to install in packaging lines for quality inspection, although the pigment concentration in the fruit and the temperature dependency are limiting factors [103,105].

\section{X-ray Computed Tomography (CT)}

Through CT, the interior part of any solid object can be visualized. It is also a nondestructive method. Digital information on the properties of the object can be generated through it. X-ray tubes are mainly used as the source, but gamma rays can also be used [106]. The soxhlet method was compared by researchers to validate the efficacy of CT for fat determination in beef, and satisfactory results $(\mathrm{r}=0.92-0.99, p<0.001)$ were observed [107]. Determination of the 3D structure in a non-invasive approach and analysis of pore size, bubble distribution, wall thickness measurement, and the existence of foreign matter is possible with CT, although the cost- and time-intensive nature, operator dependency, and image artefacts (phase-contrast, cone-beam, and beam-hardening) are the limitations of CT [108].

\section{MRI Technique}

MRI is the formation of a very weak magnetization field produced by atomic nuclei of body tissue in the presence of another magnetic field. The density of the nuclei is correlated to the magnetization, and hence it shows the nature of the distribution of atoms. In an MRI, mainly hydrogen atoms are observed. Therefore, softer tissue with large water molecules can be studied well in an MRI [109]. Fat content ( $40 \pm 23 \mathrm{mg} / \mathrm{g})$ determined by an MRI demonstrated an association with GC (39 $\pm 16 \mathrm{mg} / \mathrm{g})$ in starving fish. For well-fed fish, however, there was no agreement. This could be attributable to non-triglyceride lipid synthesis in well-fed fish and MRI and GC sensitivity differences. From this study, it is obvious that the MRI may more precisely depict fat content [110]. The non-invasive and non-destructive features of this technique make it attractive for food analysis [73], but for the cost-intensive nature and difficulty in analysis of food materials in the metastable physical state (e.g., subcool materials) [111].

The physical properties, their significance in the food industry, their techniques for measurement, interpretation of the measured results, brief working principle, and the objective of the analysis have been listed in Table 1. 
Table 1. Physical properties of different food commodities.

\begin{tabular}{|c|c|c|c|c|c|c|c|c|}
\hline Physical Property & $\begin{array}{l}\text { Significance in Food } \\
\text { Industry }\end{array}$ & Unit & $\begin{array}{l}\text { Interpretation of } \\
\text { Measured Data }\end{array}$ & Measurement Technique & Principle & Measured Property & Objective of Analysis & Reference \\
\hline Water Activity (WA) & $\begin{array}{l}\text { Assessment of internal } \\
\text { structure of the food, } \\
\text { effect on food texture and } \\
\text { shelf-life assessment. }\end{array}$ & - & $\begin{array}{l}\text { WA }>0.90 \text { growth of } \\
\text { bacteria; } \\
\text { WA }<0.70 \text { growth of } \\
\text { molds inhibit; } \text { WA }<0.60 \\
\text { growth of most of the } \\
\text { microorganisms inhibit }\end{array}$ & Water activity meter. & $\begin{array}{l}\text { Ratio of the vapour pressure } \\
\text { (VP) of the water in food } \\
\text { and the VP of the pure } \\
\text { water. }\end{array}$ & $\begin{array}{l}\text { Equillibrium relative } \\
\text { humidity }\end{array}$ & $\begin{array}{l}\text { Quality characteristic } \\
\text { measurement for Sugar and } \\
\text { sugar replacers, Starch powders, } \\
\text { Agar gels. }\end{array}$ & {$[1,112]$} \\
\hline Hygroscopicity & $\begin{array}{l}\text { Assessment of a food's } \\
\text { ability to absorb moisture. }\end{array}$ & - & $\begin{array}{l}\text { Powdered food with high } \\
\text { hygroscopicity likely to } \\
\text { be clump formation with } \\
\text { simultaneous increase in } \\
\text { texture hardening }\end{array}$ & Hygrometers & $\begin{array}{l}\text { Works on the concept of } \\
\text { evaporative cooling. }\end{array}$ & $\begin{array}{l}\text { Amount of moisture } \\
\text { uptake by a specific fod } \\
\text { material }\end{array}$ & $\begin{array}{l}\text { Moisture sorption isotherm } \\
\text { modeling for starch and wheat } \\
\text { gluten, Corn starch, pepper }\end{array}$ & [113] \\
\hline Mass & $\begin{array}{l}\text { Measure for inertia and } \\
\text { heaviness of a body. }\end{array}$ & $\mathrm{kg} / \mathrm{g} / \mathrm{mg}$ & - & Weighing balance. & $\begin{array}{l}\text { A counteracting force is } \\
\text { created to be compared to } \\
\text { the unknown mass. }\end{array}$ & Quantity of matter & $\begin{array}{l}\text { To meet product formulation } \\
\text { standards and manufacturing } \\
\text { specifications }\end{array}$ & \\
\hline Density & Mass per unit volume. & $\mathrm{kg} / \mathrm{m}^{3}$ & $\begin{array}{l}>1 \mathrm{~kg} / \mathrm{m}^{3} \text { (at STP) food } \\
\text { material will sink in water }\end{array}$ & Hydrometer & $\begin{array}{l}\text { Displacement of its own } \\
\text { weight within a fluid. }\end{array}$ & Mass and volume & Alcohol concentration of drinks; & {$[1$} \\
\hline Specific Gravity & $\begin{array}{l}\text { Ratio of the absolute } \\
\text { density of a food material } \\
\text { to the density of a } \\
\text { reference material }\end{array}$ & - & $\begin{array}{l}\text { Determines whether the } \\
\text { solid food materials will } \\
\text { sink or float in liquid } \\
\text { medium }\end{array}$ & Specific gravity bottle & $\begin{array}{l}\text { Liquid densities are } \\
\text { measured by measuring the } \\
\text { weight difference between } \\
\text { an empty and filled bottle } \\
\text { and dividing by an equal } \\
\text { volume of water. }\end{array}$ & $\begin{array}{l}\text { Density of food } \\
\text { materials and water }\end{array}$ & $\begin{array}{l}\text { Solids in } \\
\text { sugar syrups; Density, specific } \\
\text { gravity and absorption of fine } \\
\text { aggregate; Specific gravity of } \\
\text { pigments. }\end{array}$ & {$[1]$} \\
\hline Particle Size & $\begin{array}{l}\text { Particles with a regular } \\
\text { shape are characterized } \\
\text { by their linear dimensions } \\
\text { (lengths) along their } \\
\text { principal axes. }\end{array}$ & $\mathrm{m} / \mathrm{cm} / \mathrm{mm}$ & $\begin{array}{l}\text { Affect the flowability, } \\
\text { solubility and reactivity, } \\
\text { and the shelf life, } \\
\text { processing condition, } \\
\text { organoleptic properties } \\
\text { and texture of the final } \\
\text { product (e.g., sieving } \\
\text { considered for }>63 \text { micron } \\
\text { particles; sedimentation } \\
\text { hindered when size } \\
<10 \mathrm{~nm} \text { ) }\end{array}$ & Particle Size Analyzer & $\begin{array}{l}\text { The angle of incidence light } \\
\text { scattering is inversely } \\
\text { proportional to particle size. }\end{array}$ & Diameter & $\begin{array}{l}\text { Texture and organoleptic } \\
\text { characterisation of chocolate, } \\
\text { fibres of grain, powdered food, } \\
\text { and sizing of protein nano-fibres. }\end{array}$ & [114-116] \\
\hline
\end{tabular}


Table 1. Cont.

\begin{tabular}{|c|c|c|c|c|c|c|c|c|}
\hline Physical Property & $\begin{array}{l}\text { Significance in Food } \\
\text { Industry }\end{array}$ & Unit & $\begin{array}{l}\text { Interpretation of } \\
\text { Measured Data }\end{array}$ & Measurement Technique & Principle & Measured Property & Objective of Analysis & Reference \\
\hline $\begin{array}{l}\text { Specific Surface Area } \\
\text { (S.A) }\end{array}$ & $\begin{array}{l}\text { Quantification of internal } \\
\text { surface area or size of } \\
\text { individual particles } \\
\text { within a disperse system }\end{array}$ & $\begin{array}{c}\mathrm{m}^{2} / \mathrm{kg} \text { or } \\
\mathrm{m}^{2} / \mathrm{g}\end{array}$ & $\begin{array}{l}\text { Materials with } 500-3000 \\
\mathrm{~m}^{2} / \mathrm{g} \mathrm{S} \text {.A suitable for } \\
\text { solute and gas absorption; } \\
200 \mathrm{~m}^{2} / \mathrm{g} \text { S.A suitable for } \\
\text { catalyst }\end{array}$ & $\begin{array}{l}\text { Brunauer-Emmett-Teller } \\
\text { (BET) surface area } \\
\text { analysis }\end{array}$ & & Surface area & $\begin{array}{l}\text { Mass and heat transfer } \\
\text { calculation, gas and moisture } \\
\text { permiability through packaging } \\
\text { materials }\end{array}$ & \multirow{3}{*}{ [114-116] } \\
\hline Sphericity & $\begin{array}{l}\text { Compactness compared } \\
\text { with a perfect sphere of } \\
\text { same dimension. }\end{array}$ & - & $\begin{array}{l}\text { Sphericity value } \approx 1 \\
\text { (sphere), } \approx 0.00271 \text { (cube), } \\
\approx 0.00155 \text { (cylinder) }\end{array}$ & & $\begin{array}{l}\text { Ratio of the surface area of } \\
\text { an equal-volume sphere to } \\
\text { the actual surface area of the } \\
\text { particle. }\end{array}$ & $\begin{array}{l}\text { Surface area and } \\
\text { volume }\end{array}$ & $\begin{array}{l}\text { Analysis and design of food } \\
\text { process equipment }\end{array}$ & \\
\hline Sauter Diameter (SD) & $\begin{array}{l}\text { Diameter of a } \\
\text { hypothetical sphere with } \\
\text { the same specific surface } \\
\text { as the irregular shaped } \\
\text { particle. }\end{array}$ & $\underset{\mu \mathrm{m}}{\mathrm{m} / \mathrm{cm} / \mathrm{mm} /}$ & $\begin{array}{l}\text { Coarse particle }(\mathrm{SD}> \\
10 \mathrm{~mm}) ; \text { fine particle } \approx \\
1 \mathrm{~mm} \text {, ultrafine particle }< \\
0.1 \mathrm{~mm}\end{array}$ & Diameter gauge & $\begin{array}{l}\text { Ratio of surface area and } \\
\text { volume of particle }\end{array}$ & $\begin{array}{l}\text { Surface area and } \\
\text { volume }\end{array}$ & $\begin{array}{l}\text { Grinding characteristics } \\
\text { measurement for wheat grain } \\
\text { and size reduction } \\
\text { characterisation }\end{array}$ & \\
\hline Uniaxial Stress & $\begin{array}{l}\text { It is caused by a force } \\
\text { pushing or pulling the } \\
\text { body in a direction } \\
\text { perpendicular to the } \\
\text { surface of the solid body } \\
\text { upon which the force is } \\
\text { acting. }\end{array}$ & $\mathrm{Pa}$ & - & $\begin{array}{l}\text { Strain gauge hole-drilling } \\
\text { method }\end{array}$ & $\begin{array}{l}\text { Deformation around the } \\
\text { hole }\end{array}$ & Deformed area & \multirow{4}{*}{$\begin{array}{l}\text { Alginate gel: stress strain } \\
\text { behavior and viscoelasticity. } \\
\text { Fruit and vegetable puree } \\
\text { products: rheological properties. } \\
\text { Ketchup: hydrocolloids and flow } \\
\text { behaviour. } \\
\text { Powders: flow properties, } \\
\text { nonflow problems. } \\
\text { Wheat flour: rheological } \\
\text { properties using farinograph, } \\
\text { extensograph, valorigraph, } \\
\text { alveograph device. }\end{array}$} & \multirow{4}{*}{ [117-122] } \\
\hline Young's Modulus & $\begin{array}{l}\text { It is the slope of the linear } \\
\text { part of the stress-strain } \\
\text { curve for a material under } \\
\text { tension or compression. }\end{array}$ & - & $\begin{array}{l}\text { Addition fat reduces the } \\
\text { young's modulus i.e., the } \\
\text { decrease in rigidity. The } \\
\text { harder is the food } \\
\text { material the higher is the } \\
\text { young's modulus }\end{array}$ & Oscillating rod & $\begin{array}{l}\text { Estimated with the help of } \\
\text { stress-strain curve. }\end{array}$ & $\begin{array}{l}\text { Alteration in length, } \\
\text { and uniaxial stress }\end{array}$ & & \\
\hline Bulk Modulus & $\begin{array}{l}\text { The relative change in the } \\
\text { volume of a body } \\
\text { produced by a unit } \\
\text { compressive or tensile } \\
\text { stress acting uniformly } \\
\text { over its surface. }\end{array}$ & $\mathrm{Pa}$ & & - & $\begin{array}{l}\text { The measure of the ability of } \\
\text { a substance to withstand } \\
\text { changes in volume when } \\
\text { under compression on all } \\
\text { sides. It is equal to the } \\
\text { quotient of the applied } \\
\text { pressure divided by the } \\
\text { relative deformation. }\end{array}$ & Pressure and volume & & \\
\hline Shear Modulus & $\begin{array}{l}\text { It is the resulting stress } \\
\text { When a force is acting } \\
\text { parallel to a surface. }\end{array}$ & $\mathrm{Pa}$ & $\begin{array}{l}\text { The higher the shear } \\
\text { modulus the higher is the } \\
\text { rigidity of the food } \\
\text { material }\end{array}$ & - & - & Pressure and strain & & \\
\hline
\end{tabular}


Table 1. Cont.

\begin{tabular}{|c|c|c|c|c|c|c|c|c|}
\hline Physical Property & $\begin{array}{l}\text { Significance in Food } \\
\text { Industry }\end{array}$ & Unit & $\begin{array}{l}\text { Interpretation of } \\
\text { Measured Data }\end{array}$ & Measurement Technique & Principle & Measured Property & Objective of Analysis & Reference \\
\hline Newtonian Flow & $\begin{array}{l}\text { linear relationship } \\
\text { between shear stress (SS) } \\
\text { and resulting shear rate } \\
\text { (SR). }\end{array}$ & - & $\begin{array}{l}\text { Reynolds no (NR) <2000; } \\
\text { visosity not change with } \\
\text { applied force }\end{array}$ & Ball viscometer & & $\begin{array}{l}\text { Elapsed time for the } \\
\text { ball to fall under } \\
\text { gravity }\end{array}$ & \multirow{2}{*}{$\begin{array}{l}\text { Flow behaviour of liquid food } \\
\text { materials for process design, } \\
\text { quality measure and flexible } \\
\text { container design }\end{array}$} & \multirow[t]{2}{*}{ [117-122] } \\
\hline Non-Newtonian Flow & $\begin{array}{l}\text { non-linear relationship } \\
\text { between SS and SR. }\end{array}$ & - & $\begin{array}{l}\text { NR }>2000 \text {; visosity } \\
\text { change with applied force }\end{array}$ & Brookfield viscometer & & Torque & & \\
\hline $\begin{array}{l}\text { Interfacial Surface } \\
\text { Tension (IST) }\end{array}$ & $\begin{array}{l}\text { It is the force of attraction } \\
\text { between the molecules at } \\
\text { the interface of two fluids. }\end{array}$ & $\mathrm{N} / \mathrm{m}$ & $\begin{array}{l}\text { Emulsion stability } \\
\text { increases with the IST }\end{array}$ & Force tensiometer & $\begin{array}{l}\text { Du Noüy ring method; } \\
\text { Wilhelmy plate method }\end{array}$ & Force and length & $\begin{array}{l}\text { Foam stability of ice-cream; } \\
\text { Physical properties of } \\
\text { chocolate }\end{array}$ & [123] \\
\hline Permeability & $\begin{array}{l}\text { Quantification of the } \\
\text { relative ease with which a } \\
\text { transporting substance } \\
\text { can pass through the } \\
\text { material. }\end{array}$ & $\mathrm{m}^{2} / \mathrm{s}-\mathrm{Pa}$ & $\begin{array}{l}\text { Lower the permeability of } \\
\text { the packaging material } \\
\text { lower will be the shelf life } \\
\text { of the food product }\end{array}$ & $\begin{array}{l}\text { Helium Permeability } \\
\text { Meter }\end{array}$ & & Pressure, mass & \multirow{3}{*}{$\begin{array}{l}\text { Undertanding the moisture } \\
\text { transfer phenomenon during } \\
\text { drying of fruits; mass tranfer } \\
\text { phenomenon in lactose } \\
\text { crystallization, } \\
\text { Whey-protein-coated plastic } \\
\text { films; design of pulse electric } \\
\text { and ohmic heat process. }\end{array}$} & \multirow{3}{*}[124-127]{} \\
\hline Conductivity & $\begin{array}{l}\text { It can be defined as a } \\
\text { measure of electrical } \\
\text { conduction. }\end{array}$ & $\begin{array}{l}\text { Siemens per meter } \\
(\mathrm{S} / \mathrm{m})\end{array}$ & $\begin{array}{l}\text { Efficiency of pulsed } \\
\text { electric and ohmic heat } \\
\text { proces is depend on } \\
\text { conductivity of food } \\
\text { materials }\end{array}$ & conductivity meter & $\begin{array}{l}\text { It is the ability of a } \\
\text { material to conduct } \\
\text { electric current. }\end{array}$ & Resistivity & & \\
\hline Resistance & $\begin{array}{l}\text { It is a measure of the } \\
\text { opposition to current flow } \\
\text { in an electrical circuit. }\end{array}$ & $\operatorname{Ohm}(\Omega)$ & $\begin{array}{l}\text { Juiciness and tenderness } \\
\text { of meat products are } \\
\text { correlated with the } \\
\text { resistance }\end{array}$ & Ohmmeter & $\begin{array}{l}\text { Deflection of pointer to } \\
\text { left or right side in } \\
\text { ohmmeter due to current } \\
\text { passing through it } \\
\text { indicate low/high } \\
\text { resistance. }\end{array}$ & & & \\
\hline
\end{tabular}


Table 1. Cont.

\begin{tabular}{|c|c|c|c|c|c|c|c|c|}
\hline Physical Property & $\begin{array}{c}\text { Significance in Food } \\
\text { Industry }\end{array}$ & Unit & $\begin{array}{l}\text { Interpretation of } \\
\text { Measured Data }\end{array}$ & Measurement Technique & Principle & Measured Property & Objective of Analysis & Reference \\
\hline Heat capacity (HC) & $\begin{array}{l}\text { Thermal property that } \\
\text { indicates the ability of the } \\
\text { material to hold and store } \\
\text { heat. }\end{array}$ & $\begin{array}{l}\text { Joule per } \\
\text { Kelvin(J/K) }\end{array}$ & $\begin{array}{l}\text { Food materials with high } \\
\text { HC have more energy } \\
\text { and take higher cooking } \\
\text { time }\end{array}$ & $\begin{array}{l}\text { Differential scanning } \\
\text { calorimeter }\end{array}$ & $\begin{array}{l}\text { The difference in the } \\
\text { amount of heat required } \\
\text { to increase the } \\
\text { temperature of a sample } \\
\text { and reference are } \\
\text { measured as a function of } \\
\text { temperature. }\end{array}$ & $\begin{array}{l}\text { change in temperature, } \\
\text { heat flow/unit time }\end{array}$ & \multirow{4}{*}{$\begin{array}{l}\text { Characterization and } \\
\text { understanding of thermo } \\
\text { physical properties for meat; } \\
\text { modelling thermal properties } \\
\text { for cheddar cheese; } \\
\text { prediction of thermal } \\
\text { properties during freezing and } \\
\text { thawing for meat and dough; } \\
\text { thermal conductivity and heat } \\
\text { capacity for shrimp; } \\
\text { investigation for thermal } \\
\text { properties of ice-cream and } \\
\text { heat conductivity of food } \\
\text { materials }\end{array}$} & \multirow{4}{*}{ [128-130] } \\
\hline Thermal conductivity & $\begin{array}{l}\text { Heat transfer ability of } \\
\text { food }\end{array}$ & $\begin{array}{l}\text { Watts per } \\
\text { meter-Kelvin } \\
(\mathrm{W} /(\mathrm{m} \cdot \mathrm{K})\end{array}$ & $\begin{array}{l}\text { It dictates how quickly } \\
\text { heat may be evenly } \\
\text { distributed throughout } \\
\text { the food mass, affecting } \\
\text { the quality of the end } \\
\text { product. }\end{array}$ & $\begin{array}{l}\text { Thermal conductivity } \\
\text { meter (The two types of } \\
\text { thermal conductivity } \\
\text { meter are steady-state } \\
\text { and non-steady-state, also } \\
\text { called transient, } \\
\text { conductivity meters) }\end{array}$ & $\begin{array}{l}\text { Steady state (when the } \\
\text { temperature of the } \\
\text { substance being } \\
\text { measured remains } \\
\text { constant over time), } \\
\text { frequency (sensor and } \\
\text { hot-wire based method), } \\
\text { and time domain (During } \\
\text { the heating up phase, } \\
\text { transient approaches take } \\
\text { measurements) } \\
\text { techniques. }\end{array}$ & $\begin{array}{l}\text { Amount of heat } \\
\text { transfer, change in } \\
\text { temperature, surface } \\
\text { area of food material }\end{array}$ & & \\
\hline $\begin{array}{l}\text { Thermal diffusivity } \\
\text { (TD) }\end{array}$ & $\begin{array}{l}\text { It is the thermal } \\
\text { conductivity divided by } \\
\text { density and specific heat } \\
\text { capacity at constant } \\
\text { pressure. }\end{array}$ & $\begin{array}{l}\text { Square metres per } \\
\text { second }\left(\mathrm{m}^{2} \mathrm{~s}^{-1}\right)\end{array}$ & $\begin{array}{l}\text { Most of the food materials } \\
\text { lies within the range of } \\
1.05 \times 10^{7} \mathrm{~m}^{2} \mathrm{~s}^{-1} \text { (apple } \\
\text { juice) to } 1.82 \times 10^{7} \mathrm{~m}^{2} \mathrm{~s}^{-1} \\
\text { (peas). Higher the TD the } \\
\text { lower time will require to } \\
\text { cool or heat the product }\end{array}$ & $\begin{array}{l}\text { Discovery Flash } \\
\text { Diffusivity instruments }\end{array}$ & - & $\begin{array}{l}\text { Density, specific heat } \\
\text { capacity, thermal } \\
\text { conductivity }\end{array}$ & & \\
\hline Calorific value (CV) & $\begin{array}{l}\text { Heat generated due to } \\
\text { complete combustion of } \\
\text { specified quantity at } \\
\text { constant pressure under } \\
\text { normal conditions. }\end{array}$ & $\mathrm{kJ} / \mathrm{kg}$ & $\begin{array}{l}4 \mathrm{kcal} / \mathrm{g} \text { for carbohydrate } \\
\text { and protein and } 9 \mathrm{kcal} / \mathrm{g} \\
\text { for fat, higher the } \mathrm{CV} \\
\text { higher is the energy } \\
\text { content of the food }\end{array}$ & Bomb Calorimeter & $\begin{array}{l}\text { Energy released by } \\
\text { burning a representative } \\
\text { sample in a high- } \\
\text { pressure oxygen } \\
\text { atmosphere within a } \\
\text { metal pressure vessel or } \\
\text { "bomb" absorbed within } \\
\text { the calorimeter and the } \\
\text { resulting temperature } \\
\text { change within the } \\
\text { absorbing medium is } \\
\text { noted. }\end{array}$ & Increase in temperature & & \\
\hline Capacitance & $\begin{array}{l}\text { capacity of a component } \\
\text { to collect and store energy } \\
\text { in the form of an electrical } \\
\text { charge. }\end{array}$ & Farad $(\mathrm{F})$ & & capacitance meter & $\begin{array}{l}\text { The capacitance meter } \\
\text { works based on the } \\
\text { directly proportional } \\
\text { relationship between } \\
\text { capacitance and a time } \\
\text { constant. }\end{array}$ & Voltage & $\begin{array}{l}\text { Fish quality measurement } \\
\text { using electrical properties and } \\
\text { Monitoring microbial growth }\end{array}$ & [131-133] \\
\hline Inductance & $\begin{array}{l}\text { Ability of an inductor to } \\
\text { store energy. }\end{array}$ & Henry (H) & & LCR meter & - & $\begin{array}{l}\text { Cross sectional area, } \\
\text { length and current }\end{array}$ & & \\
\hline
\end{tabular}


Table 1. Cont.

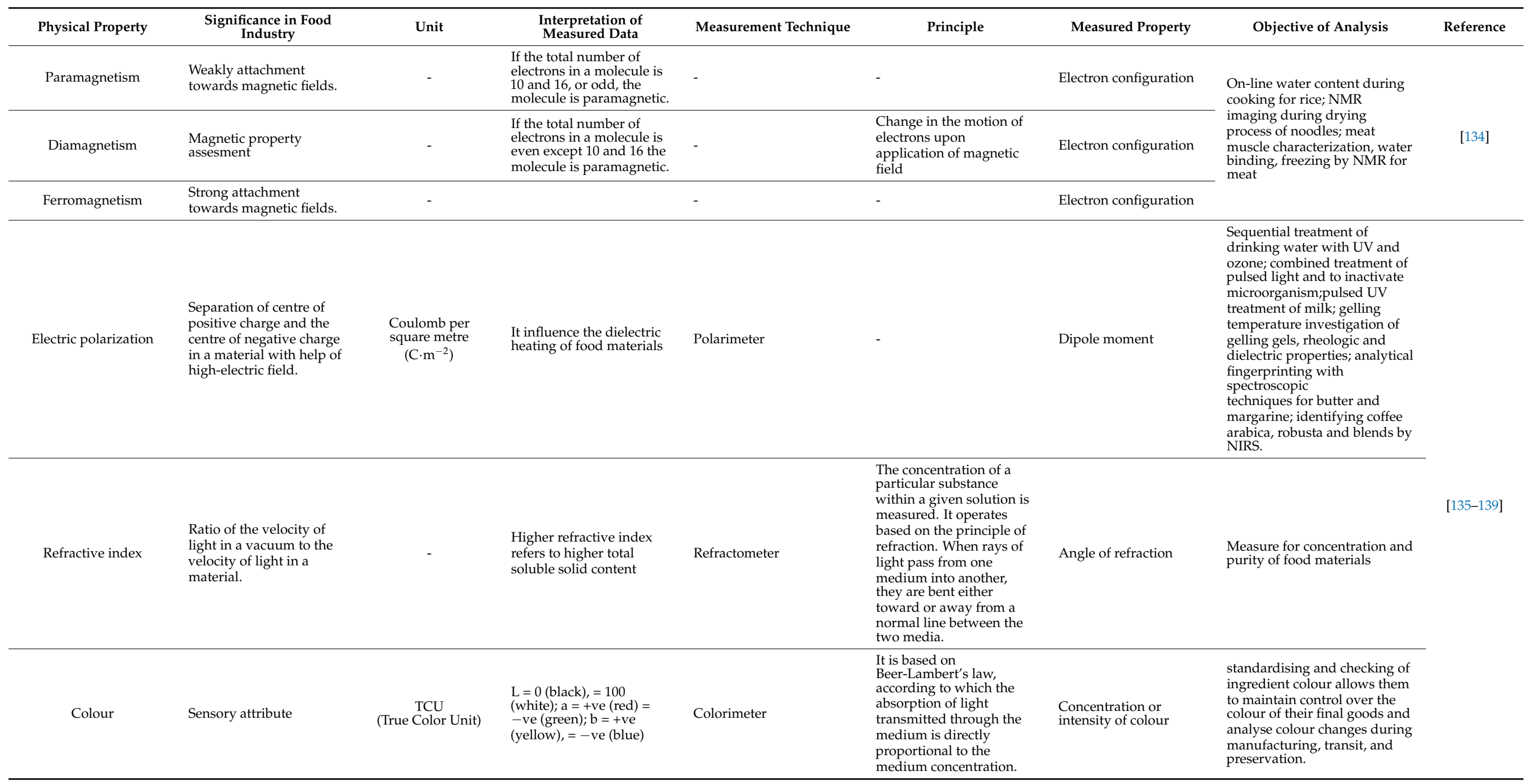


Table 2. Physical methods of analysis for different food commodities.

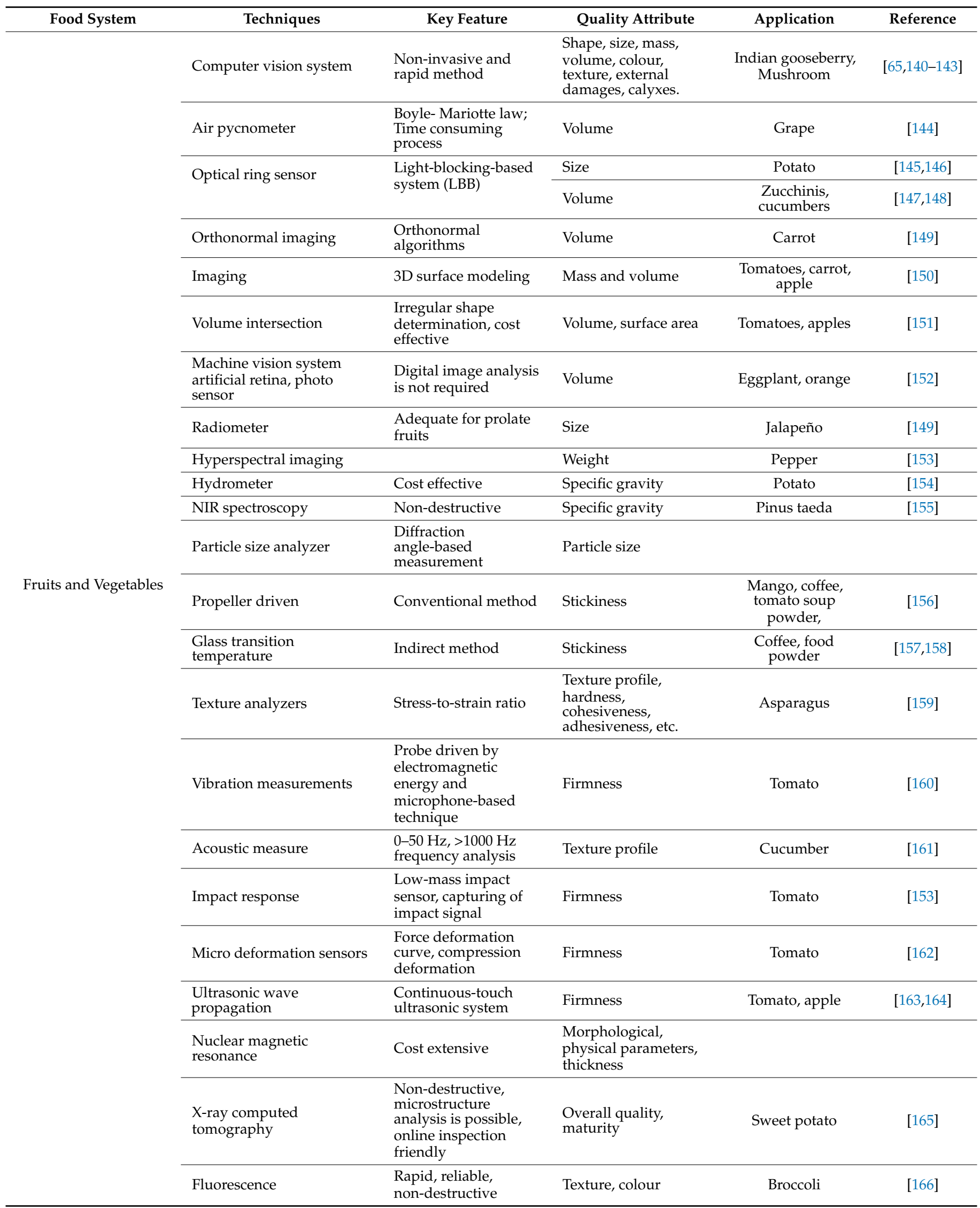


Table 2. Cont.

\begin{tabular}{|c|c|c|c|c|c|}
\hline Food System & Techniques & Key Feature & Quality Attribute & Application & Reference \\
\hline \multirow{9}{*}{ Fruits and Vegetables } & $\begin{array}{l}\text { Time-resolved diffuse } \\
\text { reflectance spectroscopy }\end{array}$ & Non-destructive & Texture & Tomato & [167] \\
\hline & Laser-scattering imaging & Non-destructive & Firmness & Tomato & {$[168]$} \\
\hline & $\begin{array}{l}\text { Friction force microscope, } \\
\text { atomic force microscopy, } \\
\text { tribometer, contact } \\
\text { profilometry, surface force } \\
\text { apparatus }\end{array}$ & $\begin{array}{l}\text { Surface contacting } \\
\text { techniques }\end{array}$ & Surface texture & Potato & [169] \\
\hline & $\begin{array}{l}\text { Confocal laser scanning } \\
\text { microscopy, fiber-optic } \\
\text { reflectometer, gloss meter, } \\
\text { surface glistening points } \\
\text { method, angle-resolved } \\
\text { light scattering }\end{array}$ & $\begin{array}{l}\text { Non surface } \\
\text { contacting techniques }\end{array}$ & $\begin{array}{l}\begin{array}{l}\text { Surface texture } \\
\text { (average roughness, }\end{array} \\
\text { root-mean square } \\
\text { roughness, average } \\
\text { slope of surface } \\
\text { asperities, peak to } \\
\text { valley height) }\end{array}$ & Tomato pulp & [170] \\
\hline & $\begin{array}{l}\text { Near infrared (IR) } \\
\text { technique }\end{array}$ & $\begin{array}{l}\text { Hyperspectral } \\
\text { imaging technique }\end{array}$ & $\begin{array}{l}\text { Scattering and } \\
\text { absorbance properties }\end{array}$ & $\begin{array}{l}\text { Zucchini squash, } \\
\text { tomatoes, } \\
\text { cucumbers }\end{array}$ & [171] \\
\hline & Resonant cavity method & $\begin{array}{l}\text { Important for } \\
\text { modelling of } \\
\text { Microwave drying }\end{array}$ & $\begin{array}{l}\text { Loss factor, dielectric } \\
\text { constant }\end{array}$ & Garlic & [172] \\
\hline & Thermistor-based method & Traditional method & Thermal conductivity & Potato & [173] \\
\hline & CT meter & Easy operate & $\begin{array}{l}\text { Thermal Diffusivity, } \\
\text { thermal conductivity }\end{array}$ & Onion powder & [174] \\
\hline & High-speed IR camera & $\begin{array}{l}\text { Rapid, } \\
\text { non-destructive }\end{array}$ & $\begin{array}{l}\text { Thermal Diffusivity, } \\
\text { thermal conductivity }\end{array}$ & Onion & [175] \\
\hline \multirow{7}{*}{ Cereal Product } & Numerical methods (NM) & $\begin{array}{l}\text { Better insight to } \\
\text { predict anomalies that } \\
\text { are difficult to predict } \\
\text { using analytical } \\
\text { approaches since it } \\
\text { can only answer a few } \\
\text { (2 to 3) unknown } \\
\text { variables, whereas } \\
\text { NM can do much } \\
\text { more. }\end{array}$ & $\begin{array}{l}\text { The grain-to-wall } \\
\text { friction coefficient, } \\
\text { internal friction angle, } \\
\text { specific weight }\end{array}$ & Silo design & [176] \\
\hline & $\begin{array}{l}\text { Triaxial test, uniaxial } \\
\text { compression test }\end{array}$ & & Modulus of elasticity & Cereal grain & [177] \\
\hline & Acoustic method & $\begin{array}{l}\text { Estimation of acoustic } \\
\text { shear wave }\end{array}$ & Modulus of elasticity & Cereal grain & [178] \\
\hline & $\begin{array}{l}\text { Computed tomography } \\
(\mathrm{CT}) \text {, ultrasound, electrical } \\
\text { tomography (ET), MRI }\end{array}$ & $\begin{array}{l}\text { Non-destructive } \\
\text { technique }\end{array}$ & $\begin{array}{l}\text { Perimeter, Elongation, } \\
\text { Area, compactness, } \\
\text { maximum width, } \\
\text { maximum length, }\end{array}$ & Barley, rice & [179] \\
\hline & $\begin{array}{l}\text { Scanning electron } \\
\text { microscopy (SEM), confocal } \\
\text { laser scanning microscopy }\end{array}$ & $\begin{array}{l}\text { Stereospecific vision, } \\
\text { higher magnification } \\
\text { and resolution }\end{array}$ & Microstructure & Rice, wheat & [180] \\
\hline & $\begin{array}{l}\text { Manometric, gravimetic, } \\
\text { hygrometric }\end{array}$ & $\begin{array}{l}\text { Manual process, } \\
\text { frequent calibration is } \\
\text { required, not work } \\
\text { properly at frost point }\end{array}$ & $\begin{array}{l}\text { Equilibrium moisture } \\
\text { content, moisture } \\
\text { sorption isotherms } \\
\text { (MSI) }\end{array}$ & Rice, grain, barley & [181] \\
\hline & Dynamic vapour sorption & $\begin{array}{l}\text { Gravimetric technique, } \\
\text { water vapour and } \\
\text { organic solvent can be } \\
\text { used }\end{array}$ & $\begin{array}{l}\text { Equilibrium moisture } \\
\text { content }\end{array}$ & Mushroom & [182] \\
\hline
\end{tabular}


Table 2. Cont.

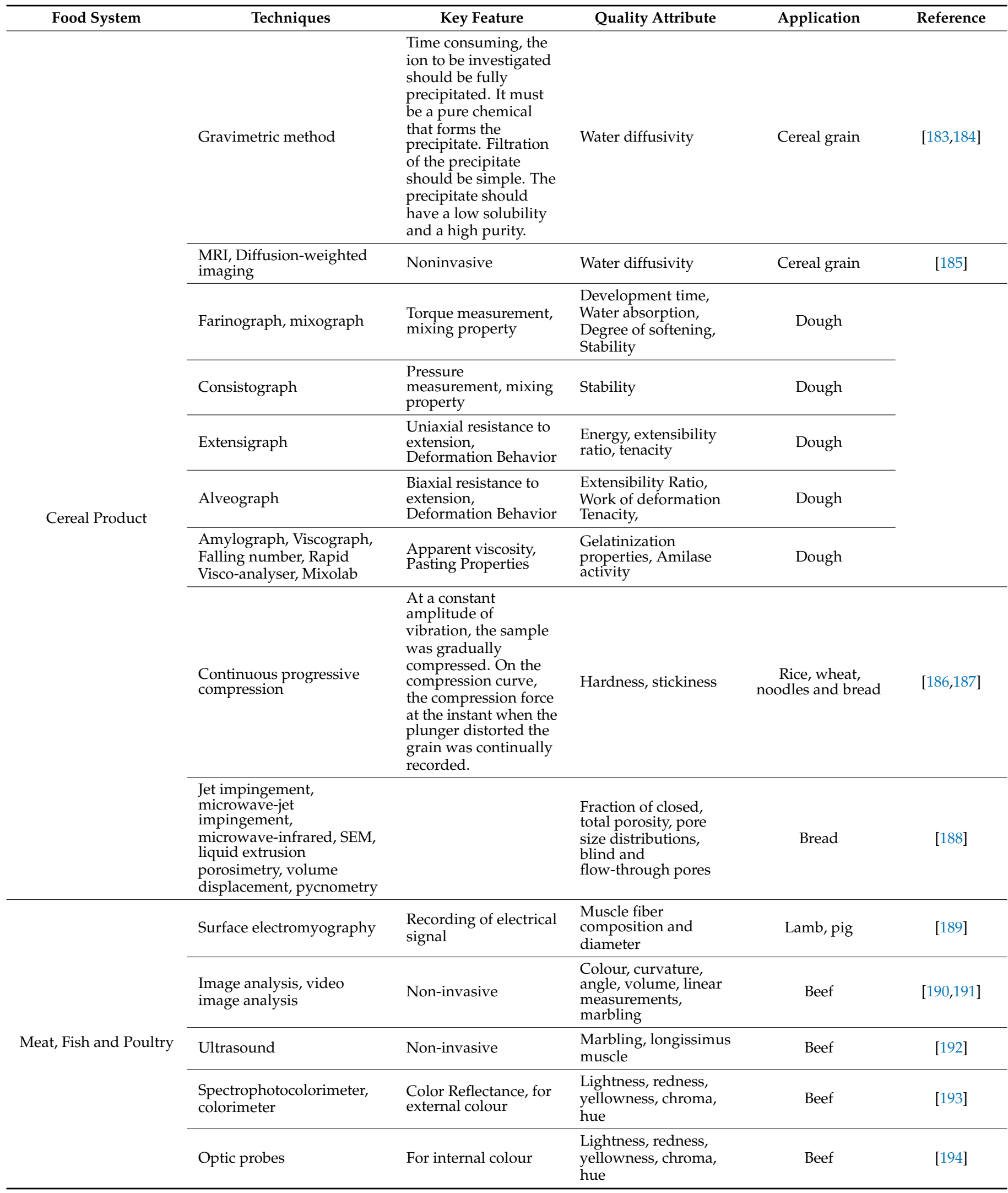


Table 2. Cont.

\begin{tabular}{|c|c|c|c|c|c|}
\hline Food System & Techniques & Key Feature & Quality Attribute & Application & Reference \\
\hline \multirow{16}{*}{ Meat, Fish and Poultry } & $\begin{array}{l}\text { Visible and near-infrared } \\
\text { spectroscopy }\end{array}$ & Non-destructive & Tenderness & Beef & [195] \\
\hline & $\begin{array}{l}\text { Bioelectrical impedance } \\
\text { analysis, electrical } \\
\text { conductivity, magnetic } \\
\text { inductance technology }\end{array}$ & Non-destructive & Fat and lean content & Lamb & [196] \\
\hline & $\mathrm{X}$-ray CT & Lower cost alternative & $\begin{array}{l}\text { Average density and } \\
\text { area }\end{array}$ & & [197] \\
\hline & $\begin{array}{l}\text { Warner-Bratzler shear force } \\
\text { (cooked meat), compression } \\
\text { test (raw meat), Texture } \\
\text { Analyzer }\end{array}$ & Invasive method & Rheological properties & Beef & [198] \\
\hline & Beefcam & $\begin{array}{l}\text { Simplified, useful in } \\
\text { commercial } \\
\text { application }\end{array}$ & Tenderness & Beef & [199] \\
\hline & Optical reflectance & $\begin{array}{l}\text { Measurement of } \\
\text { physical } \\
\text { characteristics }\end{array}$ & Tenderness & Beef & {$[200]$} \\
\hline & $\begin{array}{l}\text { Bite tests, penetrometry, } \\
\text { tensile test }\end{array}$ & Invasive method & Tenderness & Beef & [201] \\
\hline & Digital image analysis & Non-invasive method & $\begin{array}{l}\text { Surface texture, } \\
\text { Colour, marbling }\end{array}$ & Beef & [202] \\
\hline & X-ray microtomography & Non-invasive method & Intramuscular fat & Beef & [107] \\
\hline & Hyperspectral imaging & Non-invasive method & $\begin{array}{l}\text { Colour, marbling, drip } \\
\text { loss }\end{array}$ & Pork & [203] \\
\hline & Viscometer & $\begin{array}{l}\text { Fluid friction } \\
\text { measurement }\end{array}$ & Viscosity & $\begin{array}{l}\text { Low-fat meat } \\
\text { batters }\end{array}$ & [204] \\
\hline & Finite element method & $\begin{array}{l}\text { Computer simulation } \\
\text { model }\end{array}$ & Thermal conductivity & Meat emulsion & [205] \\
\hline & Image analysis & Non-invasive method & $\begin{array}{l}\text { Visual appearance, } \\
\text { taste, texture }\end{array}$ & Ham & [206] \\
\hline & $\begin{array}{l}\text { Lacunarity analysis, } \\
\text { variogram }\end{array}$ & Non-invasive method & $\begin{array}{l}\text { Fat-connective tissue, } \\
\text { pores }\end{array}$ & Ham & [206] \\
\hline & NIR spectroscopy & $\begin{array}{l}\text { Provide results closer } \\
\text { to true quantitative } \\
\text { value and fast method }\end{array}$ & Brightness, oiliness & Iberian pig fat & [207] \\
\hline & $\begin{array}{l}\text { Differential scanning } \\
\text { calorimetry }\end{array}$ & $\begin{array}{l}\text { Non-invasive and fast } \\
\text { method }\end{array}$ & $\begin{array}{l}\text { Melting properties, } \\
\text { thermal behaviour }\end{array}$ & Dry cured ham & [208] \\
\hline \multirow{7}{*}{ Dairy product } & $\begin{array}{l}\text { Static light scattering } \\
\text { (Malvern Mastersizer) }\end{array}$ & $\begin{array}{l}\text { Measurement of } \\
\text { refractive index }\end{array}$ & Particle size & Milk powder & [209] \\
\hline & Powder tester & & $\begin{array}{l}\text { Cohesion, } \\
\text { Compressibility, } \\
\text { Packed, and Bulk } \\
\text { densities, angle of } \\
\text { spatula, angle of } \\
\text { repose }\end{array}$ & Milk powder & {$[210]$} \\
\hline & Micromeritis pycnometer & $\begin{array}{l}\text { Measured by the } \\
\text { change in gas pressure }\end{array}$ & Density and volume & Milk powder & {$[211]$} \\
\hline & Shear cell technique & Traditional method & $\begin{array}{l}\text { Wall friction, internal } \\
\text { friction, flow function }\end{array}$ & Milk powder & {$[212]$} \\
\hline & Annular shear cell & & $\begin{array}{l}\text { Effective angle of } \\
\text { internal friction, flow } \\
\text { function }\end{array}$ & Milk powder & [209] \\
\hline & Angle of repose & $\begin{array}{l}\text { Static measure of } \\
\text { relative flowability }\end{array}$ & Flow function & Milk powder & {$[213]$} \\
\hline & Pneumatic techniques & Direct method & $\begin{array}{l}\text { Cohesiveness, } \\
\text { adhesiveness, } \\
\text { sticky-point } \\
\text { temperature }\end{array}$ & Milk powder & {$[214]$} \\
\hline
\end{tabular}


Table 2. Cont.

\begin{tabular}{|c|c|c|c|c|c|}
\hline Food System & Techniques & Key Feature & Quality Attribute & Application & Reference \\
\hline \multirow{23}{*}{ Dairy product } & Propeller-driven method & Simple, easy to use & $\begin{array}{l}\text { Sticky-point } \\
\text { temperature }\end{array}$ & Milk powder & [215] \\
\hline & Ampule method & Simple, easy to use & $\begin{array}{l}\text { Surface caking } \\
\text { temperature }\end{array}$ & Milk powder & [216] \\
\hline & Unconfined yield test & Simple, easy to use & Cohesiveness & Milk powder & {$[217]$} \\
\hline & Viscometer technique & $\begin{array}{l}\text { Provide results closer } \\
\text { to true quantitative } \\
\text { value and simple }\end{array}$ & Stickiness, torque & Milk powder & [215] \\
\hline & $\begin{array}{l}\text { Force-displacement cake } \\
\text { strength determination }\end{array}$ & Easy to use & Caking strength & Milk powder & [209] \\
\hline & Particle-gun method & $\begin{array}{l}\text { Venturi funnel } \\
\text { arrangement }\end{array}$ & Stickiness & Milk powder & [218] \\
\hline & Fluidized bed rig & Easy to use & Sticky-point & Milk powder & [219] \\
\hline & Cyclone test & $\begin{array}{l}\text { Rotary motion } \\
\text { generation }\end{array}$ & Stickiness & Milk powder & [220] \\
\hline & $\begin{array}{l}\text { Thermal mechanical } \\
\text { compression test }\end{array}$ & $\begin{array}{l}\text { Thermal compression } \\
\text { test }\end{array}$ & $\begin{array}{l}\text { Glass-rubber } \\
\text { transition }\end{array}$ & Milk powder & {$[214]$} \\
\hline & Rheometer & Rheological technique & $\begin{array}{l}\text { Glass-rubber } \\
\text { transition }\end{array}$ & Milk powder & [221] \\
\hline & $\begin{array}{l}\text { Static and dynamic wetting } \\
\text { tests }\end{array}$ & Easy to use & Wettability & Milk powder & [213] \\
\hline & $\begin{array}{l}\text { Rehydration method, NMR } \\
\text { relaxometry }\end{array}$ & Simple, easy to use & Solubility index & Milk powder & [210] \\
\hline & $\begin{array}{l}\text { Confocal scanning laser } \\
\text { microscopy, SEM, X-ray } \\
\text { photoelectron spectroscopy }\end{array}$ & $\begin{array}{l}\text { Stereospecific vision, } \\
\text { higher magnification } \\
\text { and resolution }\end{array}$ & Microstructure & Milk powder & \\
\hline & Melting thermogram & Easy to use & Melting behaviour & Butter & [222] \\
\hline & $\mathrm{Nmr}$ & $\begin{array}{l}\text { On-line phase } \\
\text { transition monitoring }\end{array}$ & $\begin{array}{l}\text { Phase transition } \\
\text { temperature }\end{array}$ & Cream & [223] \\
\hline & $\begin{array}{l}\text { Ultrasonic velocimetry, } \\
\text { pulsed NMR, ultrasonic } \\
\text { spectrometry }\end{array}$ & $\begin{array}{l}\text { Online crystallization } \\
\text { process monitoring }\end{array}$ & Solid fat content & Anhydrous milk fat & {$[120]$} \\
\hline & Penetrometry test & Easy to use & $\begin{array}{l}\text { Textural property, } \\
\text { Adhesiveness }\end{array}$ & Butter & [222] \\
\hline & Texture analyzer with a rig & Easy to use & Spreadability & Butter & [224] \\
\hline & $\begin{array}{l}\text { Parallel plate rheometer, } \\
\text { scraper-rheometer }\end{array}$ & Easy to use & Viscoelasticity & Butter & {$[222]$} \\
\hline & X-ray diffraction & Non-invasive method & Crystallinity & Butter & [225] \\
\hline & Brookfield viscosity & & & & [226] \\
\hline & Drainage & $\begin{array}{l}\text { Spontaneous, easy to } \\
\text { use }\end{array}$ & $\begin{array}{l}\text { Water-holding } \\
\text { capacity }\end{array}$ & Butter & [226] \\
\hline & $\begin{array}{l}\text { Oscillatory rheometry, } \\
\text { viscosity, turbidity, } \\
\text { dynamic light scattering, } \\
\text { thromboelastography, } \\
\text { electrical conductivity, } \\
\text { vibrational viscometry, } \\
\text { thermal conductivity } \\
\text { near-infrared spectroscopy, } \\
\text { refractometry, diffusing } \\
\text { wave spectroscopy, } \\
\text { microscopy, } \\
\text { electroacoustics, } \\
\text { fluorescence spectroscopy } \\
\text { and low- and } \\
\text { high-frequency ultrasound }\end{array}$ & Rapid & $\begin{array}{l}\text { Curd setting, textural } \\
\text { property }\end{array}$ & Cheese & [227] \\
\hline
\end{tabular}


Table 2. Cont.

\begin{tabular}{clll}
\hline Food System & \multicolumn{1}{c}{ Techniques } & \multicolumn{1}{c}{ Key Feature } & Quality Attribute \\
\hline & $\begin{array}{l}\text { Bending test, Puncture, } \\
\text { wire cutting test, dynamic } \\
\text { and transient oscillation, } \\
\text { uniaxial compression, cone } \\
\text { penetration, torsion }\end{array}$ & Rapid & $\begin{array}{l}\text { Springiness, hardness, } \\
\text { cohesiveness, } \\
\text { adhesiveness }\end{array}$ \\
\cline { 2 - 5 } & Centrifugation, gravity loss & $\begin{array}{l}\text { Higher variability } \\
\text { between results }\end{array}$ & $\begin{array}{l}\text { Water retention } \\
\text { capacity }\end{array}$ \\
\cline { 2 - 4 } & $\begin{array}{l}\text { Cryo SEM, fluorescence } \\
\text { microscopy }\end{array}$ & $\begin{array}{l}\text { Stereospecific vision, } \\
\text { higher magnification } \\
\text { and resolution }\end{array}$ & Microstructure \\
\hline
\end{tabular}

\section{Conclusions}

Mainly traditional/conventional and some novel analysis techniques have been considered here. The conventional methods are easy to implement and are cost effective, and the instruments are easily available. Thus, they are widely acceptable in industry. Conventional analysis methods applied to examine the physical properties of food material are associated with several disadvantages, such as their destructive nature, long process time, and laborious nature. To mitigate these limitations, it is extremely important to use novel technologies like MRI, NMR, UDV, acoustic methods, CT, and sensor-based methodologies. Several emerging techniques have been employed to characterize the physical properties of food materials. It has been observed that not only are they non-destructive in nature, but the results are also closer to the true quantitative values. Although several emerging techniques currently in use are discussed in this work, the replacement conventional methods with novel techniques must be developed at a faster rate.

Author Contributions: Conceptualization, T.S., M.S. and K.K.; methodology, T.S., M.S., K.K., M.R. and M.K.; formal analysis, T.S., M.S. and K.K.; investigation T.S., M.S., K.K., S.P. (Siddhartha Pati), L.T., M.T. and N.K.; writing-original draft preparation, T.S., M.S., K.K., S.P. (Svetlana Panasenko), S.A. and L.G.; writing-review and editing, T.S., M.S., K.K., F.M., I.N., A.K., J.M.L., M.A.S., M.R. and M.K. All authors have read and agreed to the published version of the manuscript.

Funding: This research received no external funding.

Institutional Review Board Statement: Not applicable.

Informed Consent Statement: Not applicable.

Data Availability Statement: All data are presented within the article.

Acknowledgments: Thanks to GAIN (Axencia Galega de Innovación) for supporting this research (Grant Number IN607A2019/01). Thanks to Principal-in-charge and staff members of Malda Polytechnic for their support.

Conflicts of Interest: The authors declare no conflict of interest.

\section{References}

1. Figura, L.O.; Teixeira, A.A. Food Physics: Physical Properties-Measurement and Applications; Springer: Berlin, Germany, $2010 ;$ p. 550.

2. Berk, Z. Physical properties of food materials. Food Process Eng. Technol. 2018, 8, 1-29. [CrossRef]

3. Joardder, M.U.H.; Karim, A.; Kumar, C.; Brown, R.J. Food as a Material; Springer: Berlin, Germany, 2016; pp. 5-13. [CrossRef]

4. Bhuyan, M. Measurement and Control in Food Processing; CRC Press: Boca Raton, FL, USA, 2006; pp. 1-340. [CrossRef]

5. Gebremariam, M.K.; Vaqué-Crusellas, C.; Andersen, L.F.; Stok, F.M.; Stelmach-Mardas, M.; Brug, J.; Lien, N. Measurement of availability and accessibility of food among youth: A systematic review of methodological studies. Int. J. Behav. Nutr. Phys. Act. 2017, 14, 1-19. [CrossRef] [PubMed]

6. Maxwell, A.L.; Gardiner, E.; Loxton, N.J. Investigating the relationship between reward sensitivity, impulsivity, and food addiction: A systematic review. Eur. Eat. Disord. Rev. 2020, 28, 368-384. [CrossRef] [PubMed]

7. Sarkar, T.; Salauddin, M.; Pati, S.; Chakraborty, R.; Shariati, M.A.; Rebezov, M.; Ermolaev, V.; Mirgorodskaya, M.; Pateiro, M.; Lorenzo, J.M. The Fuzzy Cognitive Map-Based Shelf-life Modelling for Food Storage. Food Anal. Methods 2021, 14, 147. [CrossRef]

8. Steele, D.J.; McFarlane, I. Process measurement in the food industry-1. Meas. Control 1981, 14, 24-28. [CrossRef] 
9. Soltanali, H.; Khojastehpour, M.; Torres Farinha, J. Measuring the production performance indicators for food processing industry. Measurement 2021, 173, 108394. [CrossRef]

10. Perrot, N.; Trelea, I.C.; Baudrit, C.; Trystram, G.; Bourgine, P. Modelling and analysis of complex food systems: State of the art and new trends. Trends Food Sci. Technol. 2011, 22, 304-314. [CrossRef]

11. Joardder, M.U.H.; Kumar, C.; Karim, M.A. Food structure: Its formation and relationships with other properties. Crit. Rev. Food Sci. Nutr. 2017, 57, 1190-1205. [CrossRef]

12. Toth, A.; Rendall, S.; Reitsma, F. Resilient food systems: A qualitative tool for measuring food resilience. Urban Ecosyst. 2016, 19, 19-43. [CrossRef]

13. Guiné, R.P.F.; Florença, S.G.; Barroca, M.J.; Anjos, O. The Link between the Consumer and the Innovations in Food Product Development. Foods 2020, 9, 1317. [CrossRef]

14. Nesvadba, P.; Houška, M.; Wolf, W.; Gekas, V.; Jarvis, D.; Sadd, P.A.; Johns, A.I. Database of physical properties of agro-food materials. J. Food Eng. 2004, 61, 497-503. [CrossRef]

15. Tunick, M.H.; Onwulata, C.I. Physical Methods in Food Analysis; American Chemical Society: Washington, DC, USA, 2014.

16. Joslyn, M. Methods in Food Analysis: Physical, Chemical, and Instrumental Methods of Analysis; Academic Press: San Diego, CA, USA, 1970.

17. Rajput, H.; Rehal, J.; Goswami, D.; Mandge, H.M. Methods for Food Analysis and Quality Control. In State-of-the-Art Technologies in Food Science: Human Health, Emerging Issues and Specialty Topics; Apple Academic Press: Palm Bay, FL, USA, 2019; pp. 299-346.

18. Bélanger, J.M.R.; Bissonnette, M.C.; Jocelyn Paré, J.R. Chapter 1 Chromatography: Principles and applications. In Instrumental Methods in Food Analysis; Paré, J.R.J., Bélanger, J.M.R., Eds.; Elsevier: Amsterdam, The Netherlands, 1997; Volume 18, pp. 1-35. ISBN 978-0-444-81868-3.

19. García-Cañas, V.; Simó, C.; Herrero, M.; Ibáñez, E.; Cifuentes, A. Present and Future Challenges in Food Analysis: Foodomics. Anal. Chem. 2012, 84, 10150-10159. [CrossRef] [PubMed]

20. Cifuentes, A. Food Analysis: Present, Future, and Foodomics. ISRN Anal. Chem. 2012, 2012, 801607. [CrossRef]

21. Dzantiev, B.B.; Byzova, N.A.; Urusov, A.E.; Zherdev, A.V. Immunochromatographic methods in food analysis. TrAC Trends Anal. Chem. 2014, 55, 81-93. [CrossRef]

22. Majid, I.; Nayik, G.A.; Nanda, V. Ultrasonication and food technology: A review. Cogent Food Agric. 2015, 1, 1071022. [CrossRef]

23. Yildiz, F.; Özdemir, A.T.; Uluışık, S. Evaluation Performance of Ultrasonic Testing on Fruit Quality Determination. J. Food Qual. 2019, 2019, 6810865. [CrossRef]

24. Mizrach, A. Assessing plum fruit quality attributes with an ultrasonic method. Food Res. Int. 2004, 37, 627-631. [CrossRef]

25. Mizrach, A. Ultrasonic technology for quality evaluation of fresh fruit and vegetables in pre- and postharvest processes. Postharvest Biol. Technol. 2008, 48, 315-330. [CrossRef]

26. Ross, K.A.; Pyrak-Nolte, L.J.; Campanella, O.H. The use of ultrasound and shear oscillatory tests to characterize the effect of mixing time on the rheological properties of dough. Food Res. Int. 2004, 37, 567-577. [CrossRef]

27. Li, C.; Zheng, Y.; Kwabena, A. Prediction of IMF Percentage of Live Cattle by Using Ultrasound Technologies with High Accuracies. In Proceedings of the 2009 WASE International Conference on Information Engineering, Taiyuan, China, 10-11 July 2009; Volume 2, pp. 474-478.

28. Hæggström, E.; Luukkala, M. Ultrasound detection and identification of foreign bodies in food products. Food Control 2001, 12, 37-45. [CrossRef]

29. Awad, T.S.; Moharram, H.A.; Shaltout, O.E.; Asker, D.; Youssef, M.M. Applications of ultrasound in analysis, processing and quality control of food: A review. Food Res. Int. 2012, 48, 410-427. [CrossRef]

30. Gallo, M.; Ferrara, L.; Naviglio, D. Application of Ultrasound in Food Science and Technology: A Perspective. Foods 2018, 7, 164. [CrossRef] [PubMed]

31. Ogawa, Y.; Matsuura, M.; Yamamoto, N. Young's Modulus and Poisson's Ratio Changes in Japanese Radish and Carrot Root Tissues during Boiling. Int. J. Food Prop. 2015, 18, 1006-1013. [CrossRef]

32. Fauzi, N.A.; Farid, M.M.; Silva, F. An insight on the relationship between food compressibility and microbial inactivation during high pressure processing. J. Food Sci. Technol. 2017, 54, 802-809. [CrossRef] [PubMed]

33. Torrico, D.D.; Hutchings, S.C.; Ha, M.; Bittner, E.P.; Fuentes, S.; Warner, R.D.; Dunshea, F.R. Novel techniques to understand consumer responses towards food products: A review with a focus on meat. Meat Sci. 2018, 144, 30-42. [CrossRef]

34. Ojolo, J.S.; Eweina, B.A. Predicting cashew nut cracking using hertz theory of contact stress. J. Saudi Soc. Agric. Sci. 2019, 18, 157-167. [CrossRef]

35. Li, Z.; Miao, F.; Andrews, J. Mechanical Models of Compression and Impact on Fresh Fruits. Compr. Rev. Food Sci. Food Saf. 2017, 16, 1296-1312. [CrossRef]

36. Felföldi, J.; Kertész, I.; Nagy, D.; Zsom-Muha, V. Non-destructive impact method for quality assessment of horticultural products. Prog. Agric. Eng. Sci. 2017, 13, 69-93. [CrossRef]

37. Khodabakhshian, R.; Hassani, M. The study and comparison of elastic modulus of pineapple fruit in macroscopic and microscopic modes. Microsc. Res. Tech. 2021, 84, 1348-1357. [CrossRef]

38. Walkowiak-Tomczak, D.; Idaszewska, N.; Łysiak, G.P.; Bieńczak, K. The Effect of Mechanical Vibration during Transport under Model Conditions on the Shelf-Life, Quality and Physico-Chemical Parameters of Four Apple Cultivars. Agronomy 2021, 11, 81. [CrossRef] 
39. Eissa, A.H.A.; Albaloushi, N.S.; Azam, M.M. Vibration analysis influence during crisis transport of the quality of fresh fruit on food security. Agric. Eng. Int. CIGR J. 2013, 15, 181-190.

40. Wu, D.; Sun, D.-W.; He, Y. Novel non-invasive distribution measurement of texture profile analysis (TPA) in salmon fillet by using visible and near infrared hyperspectral imaging. Food Chem. 2014, 145, 417-426. [CrossRef]

41. Breene, W.M. Application of texture profile analysis to instrumental food texture evaluation. J. Texture Stud. 1975, 6, 53-82. [CrossRef]

42. Kwon, B.S.; Lee, J.H.; Lee, K.Y.; Kim, S.J. Sensory evaluation and texture of commercial dairy and vegan types of Cheddar cheese Korean J. Food Sci. Technol. 2021, 53, 585-592.

43. Zheng, Y.; Liu, Z.; Mo, B. Texture Profile Analysis of Sliced Cheese in relation to Chemical Composition and Storage Temperature. J. Chem. 2016, 2016, 8690380. [CrossRef]

44. Zdunek, A.; Cybulska, J. Relation of biospeckle activity with quality attributes of apples. Sensors 2011, 11, 6317-6327. [CrossRef]

45. Rosenthal, A.J. Texture profile analysis-How important are the parameters? J. Texture Stud. 2010, 41, 672-684. [CrossRef]

46. Peleg, M. The instrumental texture profile analysis revisited. J. Texture Stud. 2019, 50, 362-368. [CrossRef]

47. Krol, K.; Niderla, K.; Dmowski, A.; Cichorzewska, M. Industrial Tomography Platform for Diagnostics and Control of the Crystallization Process. Eur. Res. Stud. J. 2021, XXIV, 587-596. [CrossRef]

48. Cullen, P.J.; Duffy, A.P.; O’Donnell, C.P.; O'Callaghan, D.J. Process viscometry for the food industry. Trends Food Sci. Technol. 2000, 11, 451-457. [CrossRef]

49. Choi, Y.J.; Mccarthy, K.L.; Mccarthy, M.J. Tomographic Techniques for Measuring Fluid Flow Properties. J. Food Sci. 2002, 67, 2718-2724. [CrossRef]

50. Shin, S.; Keum, D.-Y. Viscosity measurement of non-Newtonian fluid foods with a mass-detecting capillary viscometer. J. Food Eng. 2003, 58, 5-10. [CrossRef]

51. Tan, C.; Murai, Y.; Liu, W.; Tasaka, Y.; Dong, F.; Takeda, Y. Ultrasonic Doppler Technique for Application to Multiphase Flows: A Review. Int. J. Multiph. Flow 2021, 144, 103811. [CrossRef]

52. Qin, J.; Kim, M.S.; Chao, K.; Chan, D.E.; Delwiche, S.R.; Cho, B.-K. Line-Scan Hyperspectral Imaging Techniques for Food Safety and Quality Applications. Appl. Sci. 2017, 7, 125. [CrossRef]

53. Saggin, R.; Coupland, J.N. Oil viscosity measurement by ultrasonic reflectance. JAOCS J. Am. Oil Chem. Soc. 2001, 78, 509-511. [CrossRef]

54. Hauptmann, P.; Hoppe, N.; Püttmer, A. Application of ultrasonic sensors in the process industry. Meas. Sci. Technol. 2002, 13, R73-R83. [CrossRef]

55. Fathizadeh, Z.; Aboonajmi, M.; Hassan-Beygi, S.R. Nondestructive methods for determining the firmness of apple fruit flesh. Inf. Process. Agric. 2021, 8, 515-527. [CrossRef]

56. Li, B.; Lecourt, J.; Bishop, G. Advances in Non-Destructive Early Assessment of Fruit Ripeness towards Defining Optimal Time of Harvest and Yield Prediction-A Review. Plants 2018, 7, 3. [CrossRef]

57. Vursavus, K.K.; Yurtlu, Y.B.; Diezma-Iglesias, B.; Lleo-Garcia, L.; Ruiz-Altisent, M. Classification of the firmness of peaches by sensor fusion. Int. J. Agric. Biol. Eng. 2015, 8, 104-115. [CrossRef]

58. Kuswandi, B.; Siddiqui, M.W. Sensor-Based Quality Assessment Systems for Fruits and Vegetables; Apple Academic Press: Palm Bay, FL, USA, 2020.

59. García-Ramos, F.J.; Valero, C.; Homer, I.; Ortiz-Cañavate, J.; Ruiz-Altisent, M. Non-destructive fruit firmness sensors: A review. Span. J. Agric. Res. 2005, 3, 61. [CrossRef]

60. Steinmetz, V.; Crochon, M.; Bellon Maurel, V.; Garcia Fernandez, J.L.; Barreiro Elorza, P.; Verstreken, L. Sensors for Fruit Firmness Assessment: Comparison and Fusion. J. Agric. Eng. Res. 1996, 64, 15-27. [CrossRef]

61. Pandey, N.; Pal, D.; Saha, D.; Ganguly, S. Vibration-based biomimetic odor classification. Sci. Rep. 2021, 11, 11389. [CrossRef] [PubMed]

62. Abbaszadeh, R.; Rajabipour, A.; Delshad, M.; Mahjub, M.; Ahmadi, H.; Laguë, C. Application of vibration response for the nondestructive ripeness evaluation of watermelons. Aust. J. Crop Sci. 2011, 5, 920-925.

63. Oveisi, Z.; Minaei, S.; Rafiee, S.; Eyvani, A.; Borghei, A. Application of vibration response technique for the firmness evaluation of pear fruit during storage. J. Food Sci. Technol. 2014, 51, 3261-3268. [CrossRef] [PubMed]

64. Zhu, H.; Chu, B.; Fan, Y.; Tao, X.; Yin, W.; He, Y. Hyperspectral Imaging for Predicting the Internal Quality of Kiwifruits Based on Variable Selection Algorithms and Chemometric Models. Sci. Rep. 2017, 7, 7845. [CrossRef] [PubMed]

65. Mukherjee, A.; Chatterjee, K.; Sarkar, T. Entropy-Aided Assessment of Amla ( Emblica officinalis ) Quality Using Principal Component Analysis. Biointerface Res. Appl. Chem. 2022, 12, 2162-2170. [CrossRef]

66. Wang, X. 7-Near-infrared spectroscopy for food quality evaluation. In Woodhead Publishing Series in Food Science, Technology and Nutrition; Zhong, J., Wang, X., Eds.; Woodhead Publishing: Sawston, UK, 2019; pp. 105-118. ISBN 978-0-12-814217-2.

67. Huang, Y.; Lu, R.; Chen, K. Prediction of firmness parameters of tomatoes by portable visible and near-infrared spectroscopy. J. Food Eng. 2018, 222, 185-198. [CrossRef]

68. Mishra, P.; Woltering, E.; El Harchioui, N. Improved prediction of 'Kent' mango firmness during ripening by near-infrared spectroscopy supported by interval partial least square regression. Infrared Phys. Technol. 2020, 110, 103459. [CrossRef]

69. Kim, K.B.; Jung, H.M.; Kim, M.S.; Kim, G.S. Evaluation of fruit firmness by ultrasonic measurement. Key Eng. Mater. 2004, 270-273, 1049-1054. [CrossRef] 
70. Alayed, M.; Deen, M.J. Time-Resolved Diffuse Optical Spectroscopy and Imaging Using Solid-State Detectors: Characteristics, Present Status, and Research Challenges. Sensors 2017, 17, 2115. [CrossRef]

71. Cubeddu, R.; D’Andrea, C.; Pifferi, A.; Taroni, P.; Torricelli, A.; Valentini, G.; Dover, C.; Johnson, D.; Ruiz-Altisent, M.; Valero, C. Nondestructive quantification of chemical and physical properties of fruits by time-resolved reflectance spectroscopy in the wavelength range 650-1000 nm. Appl. Opt. 2001, 40, 538-543. [CrossRef] [PubMed]

72. Hatzakis, E. Nuclear Magnetic Resonance (NMR) Spectroscopy in Food Science: A Comprehensive Review. Compr. Rev. Food Sci. Food Saf. 2019, 18, 189-220. [CrossRef] [PubMed]

73. Ebrahimnejad, H.; Ebrahimnejad, H.; Salajegheh, A.; Barghi, H. Use of Magnetic Resonance Imaging in Food Quality Control: A Review. J. Biomed. Phys. Eng. 2018, 8, 127-132. [PubMed]

74. Bizzani, M.; Flores, D.W.M.; Colnago, L.A.; Ferreira, M.D. Non-invasive spectroscopic methods to estimate orange firmness, peel thickness, and total pectin content. Microchem. J. 2017, 133, 168-174. [CrossRef]

75. Arendse, E.; Fawole, O.A.; Magwaza, L.S.; Opara, U.L. Non-destructive prediction of internal and external quality attributes of fruit with thick rind: A review. J. Food Eng. 2018, 217, 11-23. [CrossRef]

76. Tunick, M.H.; Onwulata, C.I.; Thomas, A.E.; Phillips, J.G.; Mukhopadhyay, S.; Sheen, S.; Liu, C.-K.; Latona, N.; Pimentel, M.R.; Cooke, P.H. Critical Evaluation of Crispy and Crunchy Textures: A Review. Int. J. Food Prop. 2013, 16, 949-963. [CrossRef]

77. Alonzo-Macías, M.; Montejano-Gaitán, G.; Allaf, K. Impact of Drying Processes on Strawberry (Fragaria var. Camarosa) Texture: Identification of Crispy and Crunchy Features by Instrumental Measurement. J. Texture Stud. 2014, 45, 246-259. [CrossRef]

78. Marzec, A.; Kowalska, H.; Kowalska, J.; Domian, E.; Lenart, A. Influence of Pear Variety and Drying Methods on the Quality of Dried Fruit. Molecules 2020, 25, 5146. [CrossRef]

79. Arimi, J.M.; Duggan, E.; O'Sullivan, M.; Lyng, J.G.; O'Riordan, E.D. Effect of water activity on the crispiness of a biscuit (Crackerbread): Mechanical and acoustic evaluation. Food Res. Int. 2010, 43, 1650-1655. [CrossRef]

80. Çarşanba, E.; Duerrschmid, K.; Schleining, G. Assessment of acoustic-mechanical measurements for crispness of wafer products. J. Food Eng. 2018, 229, 93-101. [CrossRef]

81. Lewicki, P.P.; Jakubczyk, E.; Marzec, A.; Cabral, C. Effect of water activity on mechanical properties of dry cereal product. Acta Agrophysica 2006, 4, 381-391.

82. Błońska, A.; Marzec, A.; Błaszczyk, A. Instrumental Evaluation of Acoustic and Mechanical Texture Properties of Short-Dough Biscuits with Different Content of Fat and Inulin. J. Texture Stud. 2014, 45, 226-234. [CrossRef]

83. Yoshioka, Y.; Horie, H.; Sugiyama, M.; Sakata, Y. Quantifying cucumber fruit crispness by mechanical measurement. Breed. Sci. 2009, 59, 139-147. [CrossRef]

84. Saeleaw, M.; Schleining, G. A review: Crispness in dry foods and quality measurements based on acoustic-mechanical destructive techniques. J. Food Eng. 2011, 105, 387-399. [CrossRef]

85. Zdunek, A.; Cybulska, J.; Konopacka, D.; Rutkowski, K. Evaluation of apple texture with contact acoustic emission detector: A study on performance of calibration models. J. Food Eng. 2011, 106, 80-87. [CrossRef]

86. Povey, M.J.W.; Harden, C.A. An application of the ultrasonic pulse echo technique to the measurement of crispness of biscuits. Int. J. Food Sci. Technol. 1981, 16, 167-175. [CrossRef]

87. Zadeike, D.; Jukonyte, R.; Juodeikiene, G.; Bartkiene, E.; Valatkeviciene, Z. Comparative study of ciabatta crust crispness through acoustic and mechanical methods: Effects of wheat malt and protease on dough rheology and crust crispness retention during storage. LWT 2018, 89, 110-116. [CrossRef]

88. Antonova, I. Determination of Crispness in Breaded Fried Chicken Nuggets Using Ultrasonic Technique. Doctoral Dissertation, Virginia Tech, Blacksburg, VA, USA, 2001. Available online: https://vtechworks.lib.vt.edu/handle/10919/36456 (accessed on 1 November 2021).

89. Chaunier, L.; Courcoux, P.; Della Valle, G.; Lourdin, D. Physical and sensory evaluation of cornflakes crispness. J. Texture Stud. 2005, 36, 93-118. [CrossRef]

90. Zdunek, A.; Bednarczyk, J. Eeefect of mannitol treatment on ultrasound emission during texture profile analysis of potato and apple tissue. J. Texture Stud. 2006, 37, 339-359. [CrossRef]

91. Zdunek, A.; Konopacka, D.; Jesionkowska, K. Crispness and crunchiness judgment of apples based on contact acoustic emmision. J. Texture Stud. 2010, 41, 75-91. [CrossRef]

92. Dias-Faceto, L.S.; Salvador, A.; Conti-Silva, A.C. Acoustic settings combination as a sensory crispness indicator of dry crispy food. J. Texture Stud. 2020, 51, 232-241. [CrossRef]

93. Arefi, A.; Moghaddam, P.A.; Mollazade, K.; Hassanpour, A.; Valero, C.; Gowen, A. Mealiness Detection in Agricultural Crops: Destructive and Nondestructive Tests: A Review. Compr. Rev. Food Sci. Food Saf. 2015, 14, 657-680. [CrossRef]

94. Armstrong, C.M.; Gehring, A.G.; Paoli, G.C.; Chen, C.-Y.; He, Y.; Capobianco, J.A. Impacts of Clarification Techniques on Sample Constituents and Pathogen Retention. Foods 2019, 8, 636. [CrossRef] [PubMed]

95. Delwiche, M.; Sarig, Y. A probe impact sensor for fruit firmness measurement. Trans. ASAE 1991, 34, 187-192. [CrossRef]

96. Ozer, N.; Engel, A.B.; Simon, E. A multiple impact approach for non-destructive measurement of fruit firmness and maturity. Trans. ASAE 1998, 41, 871-876. [CrossRef]

97. Różańska, A.; Dymerski, T.; Namieśnik, J. Novel analytical method for detection of orange juice adulteration based on ultra-fast gas chromatography. Monatshefte fur Chemie 2018, 149, 1615-1621. [CrossRef] [PubMed] 
98. Crisosto, C.H.; Labavitch, J.M. Developing a quantitative method to evaluate peach (Prunus persica) flesh mealiness. Postharvest Biol. Technol. 2002, 25, 151-158. [CrossRef]

99. Goto-Inoue, N.; Yoshimura, Y.; Zaima, N. 12-Applications of imaging techniques in food science. In Chemical Analysis of Food; Pico, Y., Ed.; Academic Press: Cambridge, MA, USA, 2020; pp. 553-575. ISBN 978-0-12-813266-1.

100. Sarkar, M.; Gupta, N.; Assaad, M. Nondestructive Food Quality Monitoring Using Phase Information in Time-Resolved Reflectance Spectroscopy. IEEE Trans. Instrum. Meas. 2020, 69, 7787-7795. [CrossRef]

101. Rizzolo, A.; Vanoli, M.; Spinelli, L.; Torricelli, A. Sensory characteristics, quality and optical properties measured by time-resolved reflectance spectroscopy in stored apples. Postharvest Biol. Technol. 2010, 58, 1-12. [CrossRef]

102. De Smedt, V.; Barreiro, P.; Verlinden, B.E.; Veraverbeke, E.A.; De Baerdemaeker, J.; Nicolaï, B.M. A mathematical model for the development of mealiness in apples. Postharvest Biol. Technol. 2002, 25, 273-291. [CrossRef]

103. Moshou, D.; Wahlen, S.; Strasser, R.; Schenk, A.; De Baerdemaeker, J.; Ramon, H. Chlorophyll Fluorescence as a Tool for Online Quality Sorting of Apples. Biosyst. Eng. 2005, 91, 163-172. [CrossRef]

104. Kalaji, H.M.; Baba, W.; Gediga, K.; Goltsev, V.; Samborska, I.A.; Cetner, M.D.; Dimitrova, S.; Piszcz, U.; Bielecki, K.; Karmowska, K.; et al. Chlorophyll fluorescence as a tool for nutrient status identification in rapeseed plants. Photosynth. Res. 2018, 136, 329-343. [CrossRef] [PubMed]

105. Song, J.; Deng, W.; Beaudry, R.M.; Armstrong, P.R. Changes in chlorophyll fluorescence of apple fruit during maturation, ripening, and senescence. HortScience 1997, 32, 891-896. [CrossRef]

106. Du, Z.; Hu, Y.; Ali Buttar, N.; Mahmood, A. X-ray computed tomography for quality inspection of agricultural products: A review. Food Sci. Nutr. 2019, 7, 3146-3160. [CrossRef]

107. Frisullo, P.; Marino, R.; Laverse, J.; Albenzio, M.; Del Nobile, M. Assessment of intramuscular fat level and distribution in beef muscles using X-ray microcomputed tomography. Meat Sci. 2010, 85, 250-255. [CrossRef]

108. Schoeman, L.; Williams, P.; du Plessis, A.; Manley, M. X-ray micro-computed tomography ( $\mu C T)$ for non-destructive characterisation of food microstructure. Trends Food Sci. Technol. 2016, 47, 10-24. [CrossRef]

109. Antequera, T.; Caballero, D.; Grassi, S.; Uttaro, B.; Perez-Palacios, T. Evaluation of fresh meat quality by Hyperspectral Imaging (HSI), Nuclear Magnetic Resonance (NMR) and Magnetic Resonance Imaging (MRI): A review. Meat Sci. 2021, 172, 108340. [CrossRef]

110. Brix, O.; Apablaza, P.; Baker, A.; Taxt, T.; Grüner, R. Chemical shift based MR imaging and gas chromatography for quantification and localization of fat in Atlantic mackerel. J. Exp. Mar. Bio. Ecol. 2009, 376, 68-75. [CrossRef]

111. McCarthy, M.J.; McCarthy, K.L. Applications of magnetic resonance imaging to food research. Magn. Reson. Imaging 1996, 14, 799-802. [CrossRef]

112. Al-Muhtaseb, A.H.; McMinn, W.A.M.; Magee, T.R.A. Water sorption isotherms of starch powders: Part 1: Mathematical description of experimental data. J. Food Eng. 2004, 61, 297-307. [CrossRef]

113. Peng, G.; Chen, X.; Wu, W.; Jiang, X. Modeling of water sorption isotherm for corn starch. J. Food Eng. 2007, 80, 562-567. [CrossRef]

114. Ziegler, G.R.; Mongia, G.; Hollender, R. The role of particle size distribution of suspended solids in defining the sensory properties of milk chocolate. Int. J. Food Prop. 2007, 4, 353-370. [CrossRef]

115. Attaie, H.; Breitschuh, B.; Braun, P.; Windhab, E.J. The functionality of milk powder and its relationship to chocolate mass processing, in particular the effect of milk powder manufacturing and composition on the physical properties of chocolate masses. Int. J. Food Sci. Technol. 2003, 38, 325-335. [CrossRef]

116. Lyu, F.; Thomas, M.; Hendriks, W.H.; van der Poel, A.F.B. Size reduction in feed technology and methods for determining, expressing and predicting particle size: A review. Anim. Feed Sci. Technol. 2020, 261, 114347. [CrossRef]

117. Cuq, B.; Gonçalves, F.; Mas, J.F.; Vareille, L.; Abecassis, J. Effects of moisture content and temperature of spaghetti on their mechanical properties. J. Food Eng. 2003, 59, 51-60. [CrossRef]

118. Juszczak, L.; Witczak, M.; Fortuna, T.; Banyś, A. Rheological properties of commercial mustards. J. Food Eng. 2004, 63, $209-217$. [CrossRef]

119. Resch, J.J.; Daubert, C.R. Rheological and physicochemical properties of derivatized whey protein concentrate powders. Int. J. Food Prop. 2007, 5, 419-434. [CrossRef]

120. Gujral, H.S.; Sharma, A.; Singh, N. Effect of hydrocolloids, storage temperature, and duration on the consistency of tomato ketchup. Int. J. Food Prop. 2007, 5, 179-191. [CrossRef]

121. Haley, T.A.; Smith, R.S. Evaluation of in-line absorption photometry to predict consistency of concentrated tomato products. LWT Food Sci. Technol. 2003, 36, 159-164. [CrossRef]

122. Ahmed, J.; Ramaswamy, H.S. Dynamic rheology and thermal transitions in meat-based strained baby foods. J. Food Eng. 2007, 78, 1274-1284. [CrossRef]

123. Chang, Y.; Hartel, R.W. Stability of air cells in ice cream during hardening and storage. J. Food Eng. 2002, 55, 59-70. [CrossRef]

124. Funebo, T.; Ahrné, L.; Prothon, F.; Kidman, S.; Langton, M.; Skjöldebrand, C. Microwave and convective dehydration of ethanol treated and frozen apple-Physical properties and drying kinetics. Int. J. Food Sci. Technol. 2002, 37, 603-614. [CrossRef]

125. Ferrando, M.; Spiess, W.E.L. Mass transfer in strawberry tissue during osmotic treatment I: Microstructural changes. J. Food Sci. 2003, 68, 1347-1355. [CrossRef]

126. Hong, S.I.; Krochta, J.M. Oxygen barrier performance of whey-protein-coated plastic films as affected by temperature, relative humidity, base film and protein type. J. Food Eng. 2006, 77, 739-745. [CrossRef] 
127. Alvi, S.A.A. Quality evaluation of goat meat by an electrical method. J. Agric. Eng. 1989, 26, 59-65.

128. Cogné, C.; Andrieu, J.; Laurent, P.; Besson, A.; Nocquet, J. Experimental data and modelling of thermal properties of ice creams. J. Food Eng. 2003, 58, 331-341. [CrossRef]

129. Maroulis, Z.B.; Saravacos, G.D.; Krokida, M.K.; Panagiotou, N.M. Thermal conductivity prediction for foodstuffs: Effect of moisture content and temperature. Int. J. Food Prop. 2007, 5, 231-245. [CrossRef]

130. Marschoun, L.T.; Muthukumarappan, K.; Gunasekaran, S. Thermal properties of cheddar cheese: Experimental and modeling. Int. J. Food Prop. 2006, 4, 383-403. [CrossRef]

131. Olafsdottir, G.; Nesvadba, P.; Di Natale, C.; Careche, M.; Oehlenschläger, J.; Tryggvadóttir, S.V.; Schubring, R.; Kroeger, M.; Heia, K.; Esaiassen, M.; et al. Multisensor for fish quality determination. Trends Food Sci. Technol. 2004, 15, 86-93. [CrossRef]

132. Ryder, J.; Ababouch, L. Food and Agriculture Organization of the United Nations. In Proceedings of the Fifth World Fish Inspection and Quality Control Congress, The Hague, The Netherlands, 20-22 October 2003; p. 162.

133. Bhosale, A.A.; Sundaram, K.K. Firmness Prediction of the Apple Using Capacitance Measurement. Procedia Technol. 2014, 12, 163-167. [CrossRef]

134. Evans, S.D.; Nott, K.P.; Kshirsagar, A.A.; Hall, L.D. The effect of freezing and thawing on the magnetic resonance imaging parameters of water in beef, lamb and pork meat. Int. J. Food Sci. Technol. 1998, 33, 317-328. [CrossRef]

135. Huang, Y.; Cavinato, A.G.; Tang, J.; Swanson, B.G.; Lin, M.; Rasco, B.A. Characterization of sol-gel transitions of food hydrocolloids with near infra-red spectroscopy. LWT Food Sci. Technol. 2007, 40, 1018-1026. [CrossRef]

136. Jaillais, B.; Morrin, V.; Downey, G. Image processing of outer-product matrices-A new way to classify samples: Examples using visible/NIR/MIR spectral data. Chemom. Intell. Lab. Syst. 2007, 86, 179-188. [CrossRef]

137. Esteban-Díez, I.; González-Sáiz, J.; Sáenz-González, C.; Pizarro, C. Coffee varietal differentiation based on near infrared spectroscopy. Talanta 2007, 71, 221-229. [CrossRef]

138. Chen, B.; Fu, X.G.; Lu, D.L. Improvement of predicting precision of oil content in instant noodles by using wavelet transforms to treat near-infrared spectroscopy. J. Food Eng. 2002, 53, 373-376. [CrossRef]

139. Singh, S. Refractive Index Measurement and its Applications. Phys. Scr. 2002, 65, 167-180. [CrossRef]

140. Mukherjee, A.; Sarkar, T.; Chatterjee, K. Freshness Assessment of Indian Gooseberry (Phyllanthus emblica) Using Probabilistic Neural Network. J. Biosyst. Eng. 2021, 46, 399-416. [CrossRef]

141. Sarkar, T.; Mukherjee, A.; Chatterjee, K. Supervised Learning Aided Multiple Feature Analysis for Freshness Class Detection of Indian Gooseberry (Phyllanthus emblica). J. Inst. Eng. Ser. A 2021. [CrossRef]

142. Sarkar, T.; Mukherjee, A.; Chatterjee, K.; Ermolaev, V.; Piotrovsky, D.; Vlasova, K.; Shariati, M.A.; Munekata, P.E.S.; Lorenzo, J.M. Edge Detection Aided Geometrical Shape Analysis of Indian Gooseberry (Phyllanthus emblica) for Freshness Classification. Food Anal. Methods 2022. [CrossRef]

143. Sarkar, T.; Mukherjee, A.; Chatterjee, K.; Shariati, M.; Rebezov, M.; Rodionova, S.; Smirnov, D.; Dominguez, R.; Lorenzo, J.M. Comparative Analysis of Statistical and Supervised Learning Models for Freshness Assessment of Oyster Mushrooms. Food Anal. Methods 2021. [CrossRef]

144. Iraguen, V.; Guesalaga, A.; Agosin, E. A portable non-destructive volume meter for wine grape clusters. Meas. Sci. Technol. 2006, 17, N92. [CrossRef]

145. Gall, H.; Muir, A.; Fleming, J.; Pohlmann, R.; Göcke, L.; Hossack, W. A ring sensor system for the determination of volume and axis measurements of irregular objects. Meas. Sci. Technol. 1998, 9, 1809. [CrossRef]

146. Gall, H. A ring sensor system using a modified polar coordinate system to describe the shape of irregular objects. MeScT 1997, 8 , 1228-1235. [CrossRef]

147. Moreda, G.P.; Ortiz-Cañavate, J.; García-Ramos, F.J.; Homer, I.R.; Ruiz-Altisent, M. Optimal operating conditions for an optical ring sensor system to size fruits and vegetables. Appl. Eng. Agric. 2005, 21, 661-670. [CrossRef]

148. Moreda, G. Design and Assessment of a System for On-Line Size Determination of Fruits and Vegetables, Using an Optical Ring Sensor; Ciudad Universitaria: Madrid, Spain, 2004.

149. Hahn, F. PH—Postharvest Technology: Automatic Jalapeño Chilli Grading by Width. Biosyst. Eng. 2002, 83, 433-440. [CrossRef]

150. Hryniewicz, M.; Sotome, I.; Anthonis, J.; Ramon, H.; De Baerdemaeker, J. 3D surface modeling with stereovision. Acta Hortic. 2005, 674, 561-565. [CrossRef]

151. Lee, D.-J.; Xu, X.; Eifert, J.D.; Zhan, P. Area and volume measurements of objects with irregular shapes using multiple silhouettes. Opt. Eng. 2006, 45, 027202. [CrossRef]

152. Kanali, C.; Murase, H.; Honami, N. Three-dimensional shape recognition using a charge-simulation method to process primary image features. J. Agric. Eng. Res. 1998, 70, 195-208. [CrossRef]

153. Pan, Y.; Li, X.; Jia, X.; Zhao, Y.; Li, H.; Zhang, L. Storage temperature without fluctuation enhances shelf-life and improves postharvest quality of peach. J. Food Process. Preserv. 2019, 43, e13881. [CrossRef]

154. Alajaji, S.A.; El-Adawy, T.A. Nutritional composition of chickpea (Cicer arietinum L.) as affected by microwave cooking and other traditional cooking methods. J. Food Compos. Anal. 2006, 19, 806-812. [CrossRef]

155. Mora, C.R.; Schimleck, L.R. Determination of specific gravity of green Pinus taeda samples by near infrared spectroscopy: Comparison of pre-processing methods using multivariate figures of merit. Wood Sci. Technol. 2009, 43, 441-456. [CrossRef]

156. Jaya, S.; Das, H. Glass Transition and Sticky Point Temperatures and Stability/Mobility Diagram of Fruit Powders. Food Bioprocess Technol. 2008, 2, 89-95. [CrossRef] 
157. Bhadra, R.; Rosentrater, K.A.; Muthukumarappan, K. Measurement of Sticky Point Temperature of Coffee Powder with a Rheometer. Int. J. Food Prop. 2013, 16, 1071-1079. [CrossRef]

158. Hashemi, N.; Milani, E.; Mortezavi, S.A.; Yazdi, F.T. Sticky Point Temperature as a Suitable Method in Evaluation of Shelf Life of Food Powders. Bull. Société R. Sci. Liège 2017, 86, 7-12. [CrossRef]

159. Rodríguez, R.; Jaramillo, S.; Heredia, A.; Guillén, R.; Jiménez, A.; Fernández-Bolaños, J. Mechanical properties of white and green asparagus: Changes related to modifications of cell wall components. J. Sci. Food Agric. 2004, 84, 1478-1486. [CrossRef]

160. De Ketelaere, B.; Howarth, M.S.; Crezee, L.; Lammertyn, J.; Viaene, K.; Bulens, I.; De Baerdemaeker, J. Postharvest firmness changes as measured by acoustic and low-mass impact devices: A comparison of techniques. Postharvest Biol. Technol. 2006, 41, 275-284. [CrossRef]

161. Sakurai, N.; Iwatani, S.I.; Terasaki, S.; Yamamoto, R. Texture evaluation of cucumber by a new acoustic vibration method. J. Jpn. Soc. Hortic. Sci. 2005, 74, 31-35. [CrossRef]

162. Hertog, M.L.A.T.M.; Ben-Arie, R.; Róth, E.; Nicolaï, B.M. Humidity and temperature effects on invasive and non-invasive firmness measures. Postharvest Biol. Technol. 2004, 1, 79-91. [CrossRef]

163. Verlinden, B.E.; De Smedt, V.; Nicola, B.M. Evaluation of ultrasonic wave propagation to measure chilling injury in tomatoes. Postharvest Biol. Technol. 2004, 32, 109-113. [CrossRef]

164. Vasighi-Shojae, H.; Gholami-Parashkouhi, M.; Mohammadzamani, D.; Soheili, A. Ultrasonic based determination of apple quality as a nondestructive technology. Sens. Bio-Sens. Res. 2018, 21, 22-26. [CrossRef]

165. Charoensiddhi, S.; Anprung, P. Bioactive compounds and volatile compounds of Thai bael fruit (Aegle marmelos (L.) Correa) as a valuable source for functional food ingredients. Int. Food Res. J. 2008, 15, 287-295.

166. Deell, J.R.; Toivonen, P.M.A. Chlorophyll Fluorescence as an Indicator of Physiological Changes in Cold-Stored Broccoli After Transfer to Room Temperature. J. Food Sci. 1999, 64, 501-503.

167. Nicolaï, B.M.; Verlinden, B.E.; Lammertyn, J.; De Baerdemaeker, J. Texture assessment of perishable products. Acta Hortic. 2003, 600, 513-519. [CrossRef]

168. Kohonen, T. The Self-Organizing Map. Proc. IEEE 1990, 78, 1464-1480. [CrossRef]

169. Montouto-Grña, M.; Fernández-Fernández, E.; Vaázquez-Odeériz, M.L.; Romero-Rodríguez, M.A. Development of a sensory profile for the specific denomination "Galician potato". Food Qual. Prefer. 2002, 13, 99-106. [CrossRef]

170. Goula, A.M.; Karapantsios, T.D.; Adamopoulos, K.G. Characterization of Tomato Pulp Stickiness during Spray Drying using a Contact Probe Method. Dry. Technol. 2007, 25, 591-598. [CrossRef]

171. Qin, J.; Lu, R. Measurement of the optical properties of fruits and vegetables using spatially resolved hyperspectral diffuse reflectance imaging technique. Postharvest Biol. Technol. 2008, 49, 355-365. [CrossRef]

172. Rakulini, R.; Kalaichelvi, S.; Prasad, S. A Review of Anti-Diarrheal Activity of Aegle marmelos. Orig. Res. Artic. Rakulini Kalaichelvi 2019, 7, 1-10. [CrossRef]

173. van Gelder, M.F. A Thermistor Based Method for Measurement of Thermal Conductivity and Thermal Diffusivity of Moist Food Materials at High Temperatures. Doctoral Dissertation, Virginia Polytechnic Institute and State University, Blacksburg, VA, USA, 1997. Available online: https:/ / www.proquest.com/openview/0672c50df1ee96b7335c7ebdc9dc055c/1?pq-origsite=gscholar\& $\mathrm{cbl}=18750 \&$ diss $=\mathrm{y}$ (accessed on 1 November 2021).

174. Kumar, S.; Pandey, A.K. Chemistry and Biological Activities of Flavonoids: An Overview. Sci. World J. 2013, $2013,162750$. [CrossRef]

175. Morikawa, J.; Hashimoto, T. Thermal imaging of micro-structured polymers with high-speed infrared camera. Smart Nano-Micro Mater. Devices 2011, 8204, 82042R. [CrossRef]

176. Moya, M.; Guaita, M.; Aguado, P.; Ayuga, F. Mechanical properties of granular agricultural materials, Part 2. Trans. ASABE 2006, 49, 479-489. [CrossRef]

177. Molenda, M.; Stasiak, M. Determination of the elastic constants of cereal grains in a uniaxial compression test. Int. Agrophysics 2002, 16, 61-65.

178. Stasiak, M.; Molenda, M.; Horabik, J. Determination of modulus of elasticity of cereals and rapeseeds using acoustic method. J. Food Eng. 2007, 82, 51-57. [CrossRef]

179. Zapotoczny, P.; Zielinska, M.; Nita, Z. Application of image analysis for the varietal classification of barley:. Morphological features. J. Cereal Sci. 2008, 48, 104-110. [CrossRef]

180. Dang, J.M.; Copeland, L. Studies of the fracture surface of rice grains using environmental scanning electron microscopy. J. Sci. Food Agric. 2004, 84, 707-713. [CrossRef]

181. Samapundo, S.; Devlieghere, F.; De Meulenaer, B.; Atukwase, A.; Lamboni, Y.; Debevere, J.M. Sorption isotherms and isosteric heats of sorption of whole yellow dent corn. J. Food Eng. 2007, 79, 168-175. [CrossRef]

182. Argyropoulos, D.; Alex, R.; Müller, J. Equilibrium moisture contents of a medicinal herb (Melissa officinalis) and a medicinal mushroom (Lentinula edodes) determined by dynamic vapour sorption. Procedia Food Sci. 2011, 1, 165-172. [CrossRef]

183. Picolli da Silva, L.; de Lourdes Santorio Ciocca, M. Total, insoluble and soluble dietary fiber values measured by enzymaticgravimetric method in cereal grains. J. Food Compos. Anal. 2005, 18, 113-120. [CrossRef]

184. McCleary, B.V.; De Vries, J.W.; Rader, J.I.; Cohen, G.; Prosky, L.; Mugford, D.C.; Champ, M.; Okuma, K. Determination of Total Dietary Fiber (CODEX Definition) by Enzymatic-Gravimetric Method and Liquid Chromatography: Collaborative Study. J. AOAC Int. 2010, 93, 221-233. [CrossRef] 
185. Gruwel, M.L.H.; Ghosh, P.K.; Latta, P.; Jayas, D.S. On the diffusion constant of water in wheat. J. Agric. Food Chem. 2008, 56, 59-62. [CrossRef]

186. Nakamura, S.; Satoh, H.; Ohtsubo, K. Palatable and Bio-Functional Wheat/Rice Products Developed from Pre-Germinated Brown Rice of Super-Hard Cultivar EM10. OUP 2014, 74, 1164-1172. [CrossRef] [PubMed]

187. Okadome, H.; Toyoshima, H.; Ohtsubo, K. Multiple Measurements of Physical Properties of Individual Cooked Rice Grains with a Single Apparatus. Cereal Chem. 1999, 76, 855-860. [CrossRef]

188. Sánchez-Pardo, M.E.; Ortiz-Moreno, A.; Mora-Escobedo, R.; Chanona-Pérez, J.J.; Necoechea-Mondragón, H. Comparison of crumb microstructure from pound cakes baked in a microwave or conventional oven. LWT Food Sci. Technol. 2008, 41, 620-627. [CrossRef]

189. Ravn, L.; Andersen, N.; Rasmussen, M.; Christensen, M.; Edwards, S.; Guy, J.; Henckel, P.; Harrison, A. De electricitatis catholici musculari-Concerning the electrical properties of muscles, with emphasis on meat quality. Meat Sci. 2008, 80, 423-430. [CrossRef] [PubMed]

190. Campos, G.F.C.; Seixas, J.L.; Barbon, A.P.A.C.; Felinto, A.S.; Bridi, A.M.; Barbon, S. Robust computer vision system for marbling meat segmentation. Electron. Lett. Comput. Vis. Image Anal. 2020, 19, 15-27. [CrossRef]

191. Chmiel, M.; Dasiewicz, K.; Słowiński, M. Quality evaluation of beef trimmings by video image analysis. Zywn. Nauk. Technol. Jakosc 2010, 17, 219-227. [CrossRef]

192. Fabbri, G.; Gianesella, M.; Gallo, L.; Morgante, M.; Contiero, B.; Muraro, M.; Boso, M.; Fiore, E. Application of Ultrasound Images Texture Analysis for the Estimation of Intramuscular Fat Content in the Longissimus Thoracis Muscle of Beef Cattle after Slaughter: A Methodological Study. Animals 2021, 11, 1117. [CrossRef]

193. Holman, B.W.B.; Hopkins, D.L. A comparison of the Nix Colour Sensor Pro ${ }^{\mathrm{TM}}$ and HunterLab MiniScan ${ }^{\mathrm{TM}}$ colorimetric instruments when assessing aged beef colour stability over $72 \mathrm{~h}$ display. Meat Sci. 2019, 147, 162-165. [CrossRef]

194. Gariépy, C.; Jones, S.D.M.; Tong, A.K.W.; Rodrigue, N. Assessment of the Colormet ${ }^{\mathrm{TM}}$ fiber optic probe for the evaluation of dark cutting beef. Food Res. Int. 1994, 27, 1-6. [CrossRef]

195. Shackelford, S.; Wheeler, T.; Koohmaraie, M. On-line classification of US Select beef carcasses for longissimus tenderness using visible and near-infrared reflectance spectroscopy. Meat Sci. 2005, 69, 409-415. [CrossRef]

196. Zollinger, B.; Farrow, R.; Lawrence, T.; Latman, N. Prediction of beef carcass salable yield and trimmable fat using bioelectrical impedance analysis. Meat Sci. 2010, 84, 449-454. [CrossRef] [PubMed]

197. Navajas, E.A.; Glasbey, C.A.; Fisher, A.V.; Ross, D.W.; Hyslop, J.J.; Richardson, R.I.; Simm, G.; Roehe, R. Assessing beef carcass tissue weights using computed tomography spirals of primal cuts. Meat Sci. 2010, 84, 30-38. [CrossRef] [PubMed]

198. Robbins, K.; Jensen, J.; Ryan, K.; Homco-Ryan, C.; McKeith, F.; Brewer, M. Consumer attitudes towards beef and acceptability of enhanced beef. Meat Sci. 2003, 65, 721-729. [CrossRef]

199. Elango, G.; Rahuman, A.A. Evaluation of medicinal plant extracts against ticks and fluke. Parasitol. Res. 2011, 108, 513-519. [CrossRef]

200. Ranasinghesagara, J.; Nath, T.; Wells, S.; Weaver, A.; Gerrard, D.; Yao, G. Imaging optical diffuse reflectance in beef muscles for tenderness prediction. Meat Sci. 2010, 84, 413-421. [CrossRef] [PubMed]

201. Lepetit, J.; Culioli, J. Mechanical properties of meat. Meat Sci. 1994, 36, 203-237. [CrossRef]

202. Jackman, P.; Sun, D.; Allen, P.; Brandon, K.; White, A. Correlation of consumer assessment of longissimus dorsi beef palatability with image colour, marbling and surface texture features. Meat Sci. 2010, 84, 564-568. [CrossRef]

203. Qiao, X.; Du, R.; Wang, Y.; Han, Y.; Zhou, Z. Isolation, Characterisation and Fermentation Optimisation of Bacteriocin-Producing Enterococcus faecium. Waste Biomass Valoriz. 2020, 11, 3173-3181. [CrossRef]

204. Choi, Y.; Choi, J.; Han, D.; Kim, H.; Lee, M.; Kim, H.; Jeong, J.; Kim, C. Characteristics of low-fat meat emulsion systems with pork fat replaced by vegetable oils and rice bran fiber. Meat Sci. 2009, 82, 266-271. [CrossRef]

205. Diéguez, P.M.; Beriain, M.J.; Insausti, K.; Arrizubieta, M.J. Thermal Analysis of Meat Emulsion Cooking Process by Computer Simulation and Experimental Measurement. Int. J. Food Eng. 2010, 6. [CrossRef]

206. Valous, N.A.; Mendoza, F.; Sun, D.W.; Allen, P. Texture appearance characterization of pre-sliced pork ham images using fractal metrics: Fourier analysis dimension and lacunarity. Food Res. Int. 2009, 42, 353-362. [CrossRef]

207. Pérez-Marín, D.; De Pedro Sanz, E.; Guerrero-Ginel, J.; Garrido-Varo, A. A feasibility study on the use of near-infrared spectroscopy for prediction of the fatty acid profile in live Iberian pigs and carcasses. Meat Sci. 2009, 83, 627-633. [CrossRef]

208. Niñoles, L.; Mulet, A.; Ventanas, S.; Benedito, J. Ultrasonic assessment of the melting behaviour in fat from Iberian dry-cured hams. Meat Sci. 2010, 85, 26-32. [CrossRef] [PubMed]

209. Fitzpatrick, J.J.; O'Callaghan, E.; O'Flynn, J. Application of a novel cake strength tester for investigating caking of skim milk powder. Food Bioprod. Process. 2008, 86, 198-203. [CrossRef]

210. Gaiani, C.; Ehrhardt, J.; Scher, J.; Hardy, J.; Desobry, S.; Banon, S. Surface composition of dairy powders observed by X-ray photoelectron spectroscopy and effects on their rehydration properties. Colloids Surf. B. Biointerfaces 2006, 49, 71-78. [CrossRef]

211. Keogh, M.K.; Murray, C.A.; O'Kennedy, B.T. Effects of ultrafiltration of whole milk on some properties of spray-dried milk powders. Int. Dairy J. 2003, 13, 995-1002. [CrossRef]

212. Jenike, A.W. Storage and flow of solids. In Bulletin of the University of Utah; The University of Utah: Salt Lake City, UT, USA, 1964; Volume 53, pp. 1-209. [CrossRef] 
213. Kim, E.; Chen, X.; Pearce, D. Effect of surface composition on the flowability of industrial spray-dried dairy powders. Colloids Surf. B Biointerfaces 2005, 46, 182-187. [CrossRef]

214. Boonyai, P.; Howes, T.; Bhandari, B. Instrumentation and testing of a thermal mechanical compression test for glass-rubber transition analysis of food powders. J. Food Eng. 2007, 78, 1333-1342. [CrossRef]

215. Özkan, N.; Walisinghe, N.; Chen, X.D. Characterization of stickiness and cake formation in whole and skim milk powders. J. Food Eng. 2002, 55, 293-303. [CrossRef]

216. Chuy, L.E.; Labuza, T.P. Caking and Stickiness of Dairy-Based Food Powders as Related to Glass Transition. J. Food Sci. 1994, 59, 43-46. [CrossRef]

217. Rennie, P.R.; Chen, X.D.; Hargreaves, C.; MacKereth, A.R. A study of the cohesion of dairy powders. J. Food Eng. 1999, 39, 277-284. [CrossRef]

218. Mendoza, F.; Valous, N.; Sun, D.; Allen, P. Characterization of fat-connective tissue size distribution in pre-sliced pork hams using multifractal analysis. Meat Sci. 2009, 83, 713-722. [CrossRef] [PubMed]

219. Murti, R.A.; Paterson, A.H.J.; Pearce, D.; Bronlund, J.E. The influence of particle velocity on the stickiness of milk powder. Int. Dairy J. 2010, 20, 121-127. [CrossRef]

220. Intipunya, P.; Shrestha, A.; Howes, T.; Bhandari, B. A modified cyclone stickiness test for characterizing food powders. J. Food Eng. 2009, 94, 300-306. [CrossRef]

221. Hogan, S.A.; Famelart, M.H.; O'Callaghan, D.J.; Schuck, P. A novel technique for determining glass-rubber transition in dairy powders. J. Food Eng. 2010, 99, 76-82. [CrossRef]

222. Vithanage, C.R.; Grimson, M.J.; Smith, B.G. Temperature on the rheology of butter, a spreadable blend and spreads. J. Texture Stud. 2009, 40, 346-369. [CrossRef]

223. Arana, I. Physical Properties of Foods: Novel Measurement Techniques and Applications; CRC Press: Boca Raton, FL, USA, 2012.

224. Glibowski, P.; Zarzycki, P.; Krzepkowska, M. The rheological and instrumental textural properties of selected table fats. Int. J. Food Prop. 2008, 11, 678-686. [CrossRef]

225. Campos, R.; Narine, S.S.; Marangoni, A.G. Effect of cooling rate on the structure and mechanical properties of milk fat and lard. Food Res. Int. 2002, 35, 971-981. [CrossRef]

226. Sodini, I.; Remeuf, F.; Haddad, S.; Corrieu, G. The relative effect of milk base, starter, and process on yogurt texture: A review. Crit. Rev. Food Sci. Nutr. 2004, 44, 113-137. [CrossRef]

227. Lucey, J. ADSA Foundation Scholar Award. Formation and physical properties of milk protein gels. J. Dairy Sci. 2002, 85, 281-294. [CrossRef]

228. Capellas, M.; Mor-Mur, M.; Sendra, E.; Guamis, B. Effect of high-pressure processing on physico-chemical characteristics of fresh goats' milk cheese (Mató). Int. Dairy J. 2001, 11, 165-173. [CrossRef]

229. Innocente, N.; Biasutti, M.; Venir, E.; Spaziani, M.; Marchesini, G. Effect of high-pressure homogenization on droplet size distribution and rheological properties of ice cream mixes. J. Dairy Sci. 2009, 92, 1864-1875. [CrossRef] [PubMed] 